\title{
Active Dendrites and Differential Distribution of Calcium Channels Enable Functional Compartmentalization of Golgi Cells
}

\author{
Stephanie Rudolph, ${ }^{1}$ Court Hull, ${ }^{2}$ and ${ }^{\circ}$ Wade G. Regehr ${ }^{1}$ \\ ${ }^{1}$ Department of Neurobiology, Harvard Medical School, Boston, Massachusetts 02115, and 2Department of Neurobiology, Duke University, Durham, North \\ Carolina 27708
}

Interneurons are essential to controlling excitability, timing, and synaptic integration in neuronal networks. Golgi cells (GoCs) serve these roles at the input layer of the cerebellar cortex by releasing GABA to inhibit granule cells (grcs). GoCs are excited by mossy fibers (MFs) and grcs and provide feedforward and feedback inhibition to grcs. Here we investigate two important aspects of GoC physiology: the properties of GoC dendrites and the role of calcium signaling in regulating GoC spontaneous activity. Although GoC dendrites are extensive, previous studies concluded they are devoid of voltage-gated ion channels. Hence, the current view holds that somatic voltage signals decay passively within $\mathrm{GoC}$ dendrites, and grc synapses onto distal dendrites are not amplified and are therefore ineffective at firing GoCs because of strong passive attenuation. Using whole-cell recording and calcium imaging in rat slices, we find that dendritic voltage-gated sodium channels allow somatic action potentials to activate voltage-gated calcium channels (VGCCs) along the entire dendritic length, with R-type and T-type VGCCs preferentially located distally. We show that R-and T-type VGCCs located in the dendrites can boost distal synaptic inputs and promote burst firing. Active dendrites are thus critical to the regulation of GoC activity, and consequently, to the processing of input to the cerebellar cortex. In contrast, we find that N-type channels are preferentially located near the soma, and control the frequency and pattern of spontaneous firing through their close association with calcium-activated potassium $\left(\mathrm{K}_{\mathrm{Ca}}\right)$ channels. Thus, VGCC types are differentially distributed and serve specialized functions within GoCs.

Key words: calcium buffering; calcium channels; calcium-activated potassium channels; cerebellum; dendritic excitability; interneuron

\section{Significance Statement}

Interneurons are essential to neural processing because they modulate excitability, timing, and synaptic integration within circuits. At the input layer of the cerebellar cortex, a single type of interneuron, the Golgi cell (GoC), carries these functions. The extent of inhibition depends on both spontaneous activity of GoCs and the excitatory synaptic input they receive. In this study, we find that different types of calcium channels are differentially distributed, with dendritic calcium channels being activated by somatic activity, boosting synaptic inputs and enabling bursting, and somatic calcium cannels promoting regular firing. We therefore challenge the current view that GoC dendrites are passive and identify the mechanisms that contribute to GoCs regulating the flow of sensory information in the cerebellar cortex.

\section{Introduction}

Throughout the brain, diverse types of interneurons provide inhibition to modulate excitability, temporal precision, and synaptic integration within neural circuits (Pouille and Scanziani,

Received Aug. 19, 2015; revised Sept. 16, 2015; accepted Sept. 25, 2015.

Author contributions: S.R., C.H., and W.G.R. designed research; S.R. and C.H. performed research; S.R., C.H., and W.G.R. analyzed data; S.R. and W.G.R. wrote the paper.

This work was supported by the National Institutes of Health Grant R01 NS032405 to W.G.R., Ruth L. Kirschstein Awards F32 NS087708 to S.R. and F32 NS060585 to C.H., and Nancy Lurie Marks Foundation and Lefler Foundation grants to W.G.R. We thank the members of the W.G.R. laboratory for comments on this manuscript and Bruce Bean for helpful discussions.
2001; Mittmann et al., 2005; Isaacson and Scanziani, 2011). The function of different interneuron types is determined by their anatomy, connectivity, and activity patterns (Somogyi and Klausberger, 2005). At the input layer of the cerebellar cortex, only a single type of interneuron, the Golgi cell (GoC), serves these roles (Eccles et al., 1964; Brickley et al., 1996; Hamann et al.,

Correspondence should be addressed to Dr. Wade G. Regehr, Harvard Medical School, 220 Longwood Avenue, Goldenson 308, Boston, MA 02115. E-mail: Wade_Regehr@hms.harvard.edu.

DOI:10.1523/JNEUROSCI.3132-15.2015

Copyright $\odot 2015$ the authors $\quad 0270-6474 / 15 / 3515492-13 \$ 15.00 / 0$ 
2002; Mitchell and Silver, 2003; Crowley et al., 2009; Duguid et al., 2012). Within the cerebellar circuit, mossy fibers (MFs) convey multimodal sensory information to the cerebellar cortex by exciting granule cells (grcs). Grcs in turn regulate the output of the cerebellar cortex by exciting its sole output neurons, the Purkinje cells. Because GoCs inhibit hundreds of grcs via their elaborate axons (Palkovits et al., 1971), they powerfully regulate input layer excitability and control the flow of sensory information (Eccles et al., 1964; Rossi and Hamann, 1998; Vos et al., 1999; Chadderton et al., 2004; Barmack and Yakhnitsa, 2008; Duguid et al., 2012). MFs also excite GoCs at their basal dendrites, allowing them to mediate feedforward inhibition ( $\mathrm{MF} \rightarrow \mathrm{GoC} \rightarrow \mathrm{grc}$ ), whereas grcs synapse onto basal and apical dendrites enabling feedback inhibition ( $\mathrm{grc} \rightarrow \mathrm{GoC} \rightarrow$ grc) (Chan-Palay and Palay, 1971a,b; Pellionisz and Szentágothai, 1973; Dieudonné, 1998; Kanichay and Silver, 2008; Cesana et al., 2013; Yaeger and Trussell, 2015). It has been established that GoCs are crucial to cerebellar function, as eliminating GoCs severely impairs motor behavior and leads to ataxia (Watanabe et al., 1998).

A central function of GoCs is to dynamically adjust input layer excitability to the volume and pattern of inputs. It is therefore necessary to clarify the intrinsic properties that enable GoCs to efficiently respond to network activity. In particular, dendritic excitability determines both whether somatic activity is relayed to the dendrites and how synaptic inputs are transferred to the soma. Because gap junctions between dendrites are thought to promote synchronous firing and network oscillations (Dugué et al., 2009; Vervaeke et al., 2010), dendritic properties may be a key determinant of circuit level activity. Moreover, because GoCs receive thousands of excitatory synapses (Pellionisz and Szentágothai, 1973), dendritic processing of these inputs determines how they drive $\mathrm{GoC}$ firing and hence feedback inhibition. In the current view, GoC dendrites lack voltage-gated conductances (Vervaeke et al., 2012); and in consequence, grc synapses are ineffective at activating GoCs to produce feedback inhibition because inputs onto apical dendrites are strongly attenuated.

GoCs fire spontaneously at 5-20 Hz (Midtgaard, 1992; Forti et al., 2006) and consequently provide ongoing inhibition to grcs. Different neuron types use specific ion channels [e.g., calcium and calcium-activated potassium $\left(\mathrm{K}_{\mathrm{Ca}}\right.$ ) channels] (Wolfart et al., 2001; Swensen and Bean, 2003; Womack and Khodakhah, 2003, 2004; Deignan et al., 2012; Benton et al., 2013) to control action potential firing. It is therefore important to identify the ion channels that regulate spontaneous activity in GoCs.

Here we investigate two critical aspects of GoC physiology: the properties of $\mathrm{GoC}$ dendrites and the role of calcium signaling in regulating $\mathrm{GoC}$ spontaneous activity. Using calcium imaging and pharmacology, we find that $\mathrm{GoC}$ dendrites express voltage-gated sodium and calcium channels (VGCCs). Dendritic sodium channels amplify depolarization provided by somatic action potentials to promote the opening of dendritic VGCCs. We also find that calcium channel types are differentially distributed and functionally specialized: R-type and T-type calcium channels are located in distal apical dendrites but are absent near the soma. We find that dendritic calcium channels can boost synaptic inputs onto distal dendrites and promote burst firing. Conversely, $\mathrm{N}$-type calcium channels are present near the soma and absent from distal dendrites, and regulate spontaneous firing through their close association with $\mathrm{K}_{\mathrm{Ca}}$ channels. Our data challenge the assumption that $\mathrm{GoC}$ dendrites are passive, and suggest that differentially distributed VGCCs can either boost synaptic inputs or regulate spontaneous firing.

\section{Materials and Methods}

Slice preparation. Acute parasagittal slices of $200-270 \mu \mathrm{m}$ thickness were prepared from Sprague Dawley rats aged P17-P25 of either sex. Sagittal slices were used for all experiments, except for those requiring PF electrical stimulation, where transverse slices were cut (see Fig. 9). Slices were cut in an ice-cold solution containing the following (in $\mathrm{mm}$ ): 130 K-gluconate, $15 \mathrm{KCl}, 0.05$ EGTA, 20 HEPES, and $25 \mathrm{~mm}$ glucose, 0.02 (R)-CPP, pH 7.4 with $\mathrm{NaOH}$. After cutting, slices were rinsed in ACSF and incubated in a submerged chamber at $32^{\circ} \mathrm{C}$ for $30 \mathrm{~min}$ in ACSF equilibrated with $95 \% \mathrm{O}_{2}$ and $5 \% \mathrm{CO}_{2}$, containing the following (in $\mathrm{mm}$ ): $125 \mathrm{NaCl}, 26 \mathrm{NaHCO}_{3}, 1.25 \mathrm{NaH}_{2} \mathrm{PO}_{4}, 2.5 \mathrm{KCl}, 1 \mathrm{MgCl}_{2}, 2 \mathrm{CaCl}_{2}$, and 25 glucose. Slices were then kept at room temperature until recording for no more than $4 \mathrm{~h}$. The gluconate-based cutting solution diminishes calcium entry into GoCs and preserves spontaneous activity (Dugué et al., 2005). We found that, when other cutting solutions were used, such as ACSF, sucrose (Vervaeke et al., 2010), or choline chloride, GoCs were more hyperpolarized and did not fire spontaneously. In addition, although we found that cerebellar slices from mice contained spontaneously active GoCs when cut in gluconate, slices from rats were of superior health. A previous study, in which it was concluded that GoC dendrites are passive, was performed with mouse slices cut using nongluconate cutting solutions (Vervaeke et al., 2012). In that study, GoCs were sufficiently hyperpolarized that they were not spontaneously active, which is consistent with elevated levels of intracellular calcium activating $\mathrm{K}_{\mathrm{Ca}}$ channels.

Electrophysiology. Visually guided whole-cell recordings were obtained with patch pipettes of 2-4 MOhm resistances pulled from borosilicate capillary glass (Sutter Instrument) with a Sutter P-97 horizontal puller. Glass electrodes were washed with acetic acid before use to remove calcium ions. Electrophysiological recordings were performed at $31^{\circ} \mathrm{C}-$ $33 \mathrm{C}^{\circ}$. For current-clamp recordings and calcium imaging, internal solution contained the following (in $\mathrm{mm}$ ): $150 \mathrm{~K}$-gluconate, $3 \mathrm{KCl}, 10$ HEPES, 3 MgATP, 0.5 NaGTP, 5 phosphocreatine-tris ${ }_{2}$, and 5 phosphocreatine- $\mathrm{Na}_{2}, 0.05-0.1$ Fluo-5F, and 0.01 Alexa 594, with $\mathrm{pH}$ adjusted to 7.2 with $\mathrm{KOH}$. When calcium indicators were not necessary for the experiment, $0.5 \mathrm{~mm}$ EGTA was included in the internal solution. In a subset of experiments (see Fig. 8), we used 10 mM EGTA, 1 or $10 \mathrm{~mm}$ BAPTA instead of Fluo-5F as indicated. The osmolarity was adjusted to $310 \mathrm{mOsm}$ for all conditions. Electrophysiology data were acquired using a Multiclamp 700B amplifier (Molecular Devices), digitized at $20 \mathrm{kHz}$ with a National Instruments USB-6229, a National Instruments PCIMIO 16E-4 board, or an ITC-18 (Instrutech), and filtered at $4 \mathrm{kHz}$. Drugs were purchased from Abcam and Tocris Bioscience. SNX-482 was purchased from Alomone Labs. All ion channel blocker peptides (SNX482 , $\omega$-agatoxin IVA, $\omega$-conotoxin GVIA, apamin, and TTX) were used in conjunction with cytochrome $\mathrm{C}(1 \mathrm{mg} / \mathrm{ml})$ to prevent nonspecific binding. Drugs were either bath-applied or delivered locally with a pneumatic picopump (World Precision Instruments). All peptide toxins were recirculated when bath-applied. For extracellular stimulation of parallel fibers, theta glass electrodes were filled with ACSF and a current pulse was applied with a stimulus isolation unit (A360, World Precision Instruments).

Imaging and analysis. Neurons were filled with a red dye (10 $\mu \mathrm{M}$ Alexa $594)$ and a green calcium-sensitive dye (50-100 $\mu \mathrm{M}$ Fluo-5F). For experiments measuring calcium buffer capacity, $200 \mu \mathrm{M}$ Fluo-5F were used. Cells were allowed to fill for 20-30 min to allow equilibration of the dyes. We used a custom two-photon laser-scanning microscope with a $40 \times$, 0.8 numerical aperture (NA) objective (Olympus Optical) and a pulsed two-photon laser (Chameleon, Coherent). Simultaneous excitation of Alexa 594 and Fluo-5F was achieved with $800 \mathrm{~nm}$ excitation. Line scans were performed over the dendrite at $500 \mathrm{~Hz}$ for $256 \mathrm{~ms}$. We converted acquired fluorescence signals to calcium concentrations using values of $\mathrm{R}_{\min }$ and $\mathrm{R}_{\max }$ (Grynkiewicz et al., 1985). $\mathrm{R}_{\min }$ and $\mathrm{R}_{\max }$ refer to the minimum ratio of green fluorescence to red fluorescence $(G / R)$ obtained under conditions of zero calcium $\left(0 \mathrm{mM} \mathrm{Ca}{ }^{2+} / 3 \mathrm{~mm}\right.$ EGTA) and the maximum ratio measured at saturating calcium $\left(3 \mathrm{mM} \mathrm{Ca}^{2+}\right)$ as described previously (Brenowitz and Regehr, 2007). Stacks of GoCs were acquired at the end of each experiment, and locations of line scans were 
marked. Acquisition of calcium imaging and electrophysiology data were controlled with custom software written in MATLAB (generously provided by Bernardo Sabatini, Harvard Medical School). Data were analyzed using custom routines written in IgorPro, AxoGraphX, Prism, and Excel. Images were further processed with ImageJ by adjusting the contrast, brightness, and image noise. Data are reported as mean \pm SEM, and statistical analysis was performed using the two-tailed Student's $t$ test, Wilcoxon signed rank test, or the Kruskal-Wallis test where indicated when Gaussian distribution of the data could not be assumed (as determined using the D'Agostino and Pearson omnibus normality test). Statistical significance was assumed at $p<0.05$.

\section{Results}

GoCs have extensive dendrites that span the molecular layer of the cerebellar cortex (Fig. 1A). Because other types of neurons that have similarly long dendrites express active dendritic conductances to enhance signaling (Magee and Johnston, 1995; Johnston et al., 1996; Kaiser et al., 2001), we reinvestigated whether GoC dendrites are passive in acute cerebellar slices of rats. Given that GoCs are particularly fragile, we used slices within $4 \mathrm{~h}$ of cutting to preserve GoC health and spontaneous firing. Recordings were obtained when GoCs fired spontaneously in cell-attached configuration, which was an indicator for good cell health. Given the delicate nature of GoCs, instead of recording directly from GoC dendrites (Vervaeke et al., 2012), we used a minimally invasive approach that is less likely to damage dendrites, and monitored dendritic signaling with two-photon calcium imaging. Experiments were performed in acute brain slices from rats aged P17-P25. Whole-cell recordings from GoC somata allowed us to monitor and manipulate electrical activity and to fill cells with a low-affinity calcium indicator $(50-100 \mu \mathrm{M}$ Fluo-5F) and a calcium-insensitive dye (10 $\mu \mathrm{M}$ Alexa 594) for anatomical visualization. To test whether a single somatically evoked action potential can elicit a calcium transient in GoC dendrites, we hyperpolarized the cell to prevent spontaneous firing (injection of -20 to $-150 \mathrm{pA}$ ), elicited an action potential with a brief depolarizing current injection (1-2 ms duration), and simultaneously measured calcium-dependent changes in fluorescence in the dendrite. We then converted the fluorescence signal (G/R) into calcium concentration (see Materials and Methods). Resting calcium was uniform throughout the dendrite (perisomatic: $60 \pm 3 \mathrm{nM}, n=88$; proximal locations: $56 \pm 6 \mathrm{nM}$, $n=34$; medial locations: $58 \pm 5 \mathrm{nM}, 82$; distal locations: $52 \pm 8$ $\mathrm{nM}, n=25 ; p=0.45$, Kruskal-Wallis test), and in a similar range as reported for other neurons (Helmchen et al., 1997; Maravall et al., 2000; Sabatini et al., 2002; A ponte et al., 2008; Evstratova et al., 2011). Somatic action potentials resulted in calcium increases throughout the entire dendritic length, and these signals were similar in size independent of dendritic location (Fig. 1A,B). A summary of responses measured in 77 cells from proximal, medial, and distal dendritic locations ( $n=204$ locations, up to 142 $\mu \mathrm{m}$ from the soma) showed considerable variability in size (Fig. $1 C$ ), but the average size of dendritic signals showed no decrement with distance from the soma (Fig. $1 C$; linear fit, $R^{2}=$ 0.00082 ; Fig. $1 D$; perisomatic locations $<10 \mu \mathrm{m}$ : average transient $55 \pm 4 \mathrm{nM}, n=77$; proximal locations at $42 \pm 3 \mu \mathrm{m}$ : $56 \pm$ $8 \mathrm{nM}, n=27$; medial locations at $73 \pm 2 \mu \mathrm{m}: 54 \pm 5 \mathrm{nM}, n=73$; and distal locations at $111 \pm 1 \mu \mathrm{m}: 64 \pm 13 \mathrm{nM}, n=22 ; p=0.70$, Kruskal-Wallis test). We hypothesize that nonuniform calcium channel distribution contributes to variability of the calcium signals. Heterogeneity of the GoC population could also be a factor. Based on numerous, in part nonoverlapping, molecular markers used to identify GoCs (Geurts et al., 2001; Simat et al., 2007), it appears that they can be divided into many subtypes that may even exhibit a continuum of properties. It is therefore not surprising that calcium increases are variable both within cells and between cells.

Because GoCs are spontaneously active, we also tested whether action potential-dependent calcium transients could be detected in continuously firing cells. Spontaneous action potentials indeed resulted in calcium transients throughout the dendrites (Fig. 1E-G,I). The amplitudes of calcium signals did not decrease with distance from the soma (representative cell in Fig. $1 E, G$; and summary data of 23 cells and 66 dendritic locations up to $133 \mu \mathrm{m}$ from the soma in Fig. $1 H$; average calcium transient at perisomatic locations: $47 \pm 6 \mathrm{nM}, n=23$; at proximal locations $37 \pm 3 \mu \mathrm{m}$ from the soma: $40 \pm 11 \mathrm{nM}, n=6$; at medial locations $78 \pm 2 \mu \mathrm{m}$ from the soma: $49 \pm 9 \mathrm{nM}, n=25$; at distal locations $118 \pm 3 \mu \mathrm{m}$ from the soma: $53 \pm 14 \mathrm{nM}, n=14$; $p=0.95$, Kruskal-Wallis test). Steady-state calcium levels also increased with firing frequency (measured at various dendritic locations; Fig. 1 I,J). These findings suggest that intracellular calcium signals in GoC dendrites strongly depend on the level of activity.

The observation that somatic action potentials in GoCs depolarize dendrites sufficiently to open VGCCs could either reflect passive spread (Stuart and Häusser, 1994; Myoga et al., 2009; Schneider et al., 2013), or it could be promoted by dendritic sodium channels (Kaiser et al., 2001; Hu et al., 2010). We used the action potential clamp (AP clamp) technique (Llinás et al., 1982) to distinguish between these two possibilities. First, we recorded a somatic action potential in current-clamp configuration that resulted in a dendritic calcium transient (Fig. $2 A$, top traces). We then blocked voltage-gated sodium channels with TTX, which abolished the action potential and the calcium transient (Fig. $2 \mathrm{~A}$, bottom traces). Bath application of TTX reduced the perisomatic calcium transient to $7 \pm 1 \%$ of control from $53 \pm 17 \mathrm{nM}$ to $4 \pm 2$ nм (Fig. $2 B ; n=9, p=0.015$, paired $t$ test). In the continued presence of TTX, we then depolarized the soma with the recorded action potential waveform in voltage-clamp configuration and measured the resulting dendritic calcium signals at different dendritic locations (Fig. 2C,D). Whereas calcium signals evoked in current clamp showed no decrement with distance from the soma (Fig. 1), those evoked by an action potential waveform in voltage clamp and in the presence of TTX attenuated strongly with distance (Fig. 2D). A summary of calcium responses measured in 23 cells and 79 dendritic locations up to $230 \mu \mathrm{m}$ from the soma is shown in Figure $2 E$ (linear fit $R^{2}=0.088$; Figure $2 F$; perisomatic dendrite: $48 \pm 16 \mathrm{nM}, n=23$, proximal dendritic locations at $35 \pm 3 \mu \mathrm{m}: 26 \pm 3 \mathrm{nM}, n=12$; medial locations at $72 \pm 3 \mu \mathrm{m}: 18 \pm 5 \mathrm{~nm}, n=22$; distal locations at $135 \pm 6 \mu \mathrm{m}: 9 \pm$ $3 \mathrm{nM}, n=20 ; p=0.0016$ ); Kruskal-Wallis test with Dunn's multiple-comparison test indicates a significant decrease in the size of the calcium transient at distal dendritic locations compared with perisomatic signals. These results suggest that dendritic sodium channels must boost the somatic depolarization sufficiently to promote the opening of dendritic VDCCs.

To further assess the contribution of dendritic sodium channels to calcium signals, we selectively blocked dendritic sodium channels by locally applying TTX to the dendrites (Fig. 3A). While recording from a GoC, action potential-dependent calcium transients were first measured at a proximal and a distal dendritic location. Dendritic calcium signals were then measured again while TTX was applied to the dendrites. We excluded cells in which TTX had spread to the soma and significantly attenuated the somatic action potential. Evoking an action potential in the soma resulted in calcium increases in the proximal and distal 

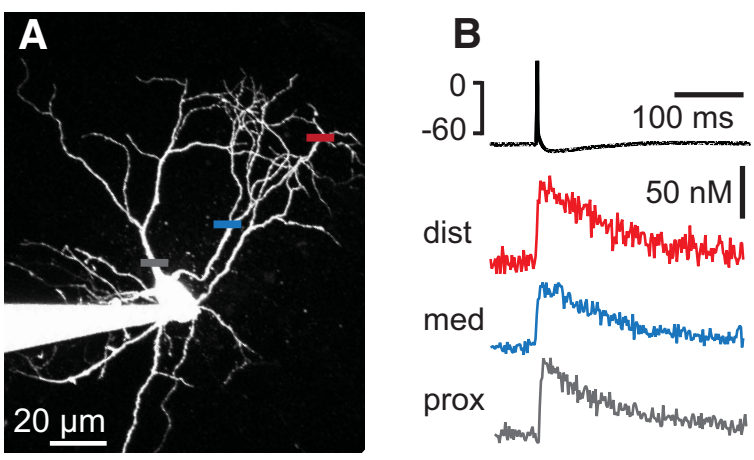

C

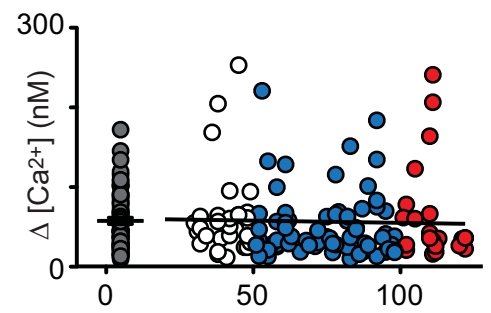

Distance from Soma $(\mu \mathrm{m})$
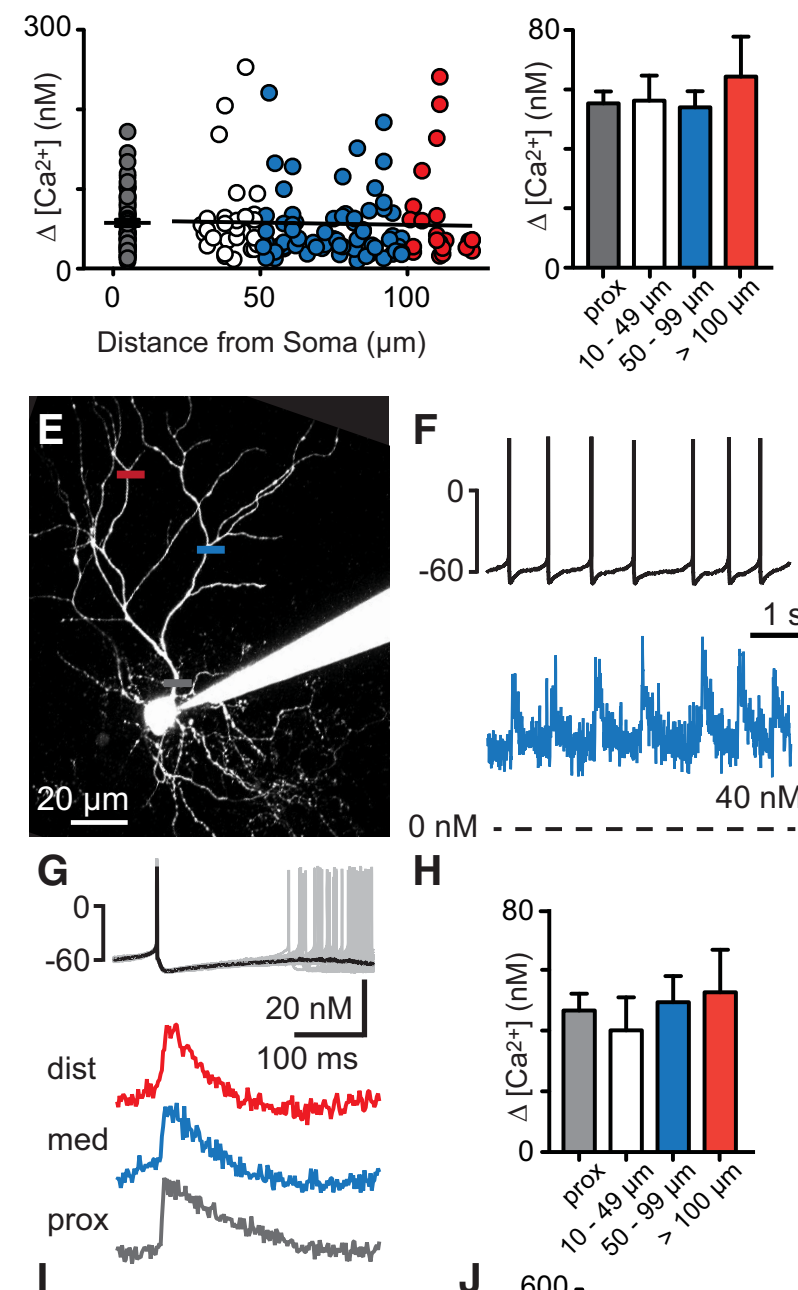

$\mathrm{H}$
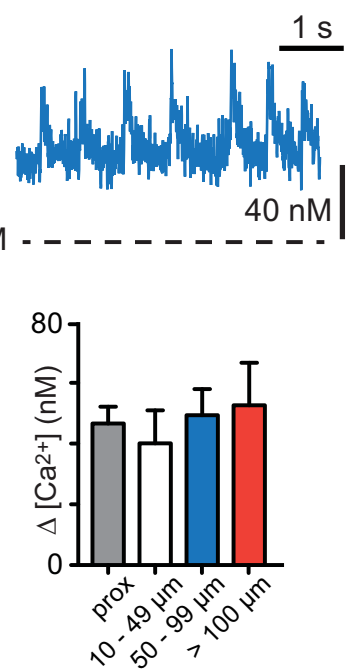

J

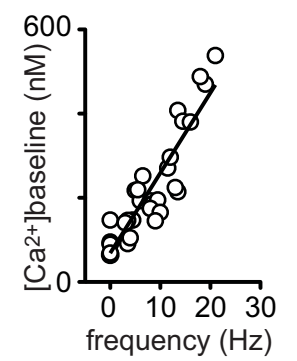

Figure 1. Action potential-dependent calcium transients in Golgi cell dendrites. A, Twophoton image of a $\mathrm{GoC}$ filled with Alexa 594 and the calcium-sensitive dye Fluo-5F. Horizontal bars represent the locations of line scans along the dendrite. $\boldsymbol{B}$, Top trace, Action potential evoked by a somatic current injection. Bottom traces, Average action potential-dependent calcium transients recorded at the locations indicated in $\boldsymbol{A}$. C, Amplitudes of dendritic calcium transients dependent on distance from the soma. D, Summary data of 77 cells with calcium

dendrites (Fig. $3 B$, top traces; $3 C, \Delta \mathrm{Ca}^{2+}=36 \pm 6 \mathrm{nM}, n=12$ and $30 \pm 3 \mathrm{~nm}, n=16 ; p>0.05$, Kruskal-Wallis test with Dunn's multiple-comparison post test). Dendritic TTX application decreased the amplitude of distal dendritic calcium signals (Fig. $3 C, D$; to $50 \pm 5 \%$ of control to $15 \pm 2 \mathrm{nM}, n=16 ; p<0.05$, Kruskal-Wallis test) without affecting calcium signals in proximal dendrites (Fig. 3B, bottom traces, and 3D; $92 \pm 7 \%$ of control, $31 \pm 5 \mathrm{nM}, n=12 ; p>0.05$, Kruskal-Wallis test). The distal TTX-dependent decrease in calcium influx recovered within $5-10 \mathrm{~min}$ (to $115 \pm 14 \%$ of control, $35 \pm 6 \mathrm{nM}, n=16 ; p>0.05$ compared with control, Kruskal-Wallis test, summary data in Fig. 3D). These results suggest that local inhibition of voltagegated sodium channels prevents the propagation of the somatic action potential and the subsequent activation of VGCCs. Together, these experiments establish that dendritic sodium channels promote the activation of VGCCs in GoC dendrites.

Different types of VGCCs can serve distinct functional roles and can be differentially distributed within neurons (Johnston et al., 1996). To determine which types of VGCCs are present in GoC dendrites, we evaluated the effect of specific calcium channel antagonists on calcium signals evoked by short bursts of action potentials in GoCs that were hyperpolarized to suppress spontaneous firing. VGCC inhibitors were applied locally to either proximal or distal regions, and calcium responses were measured in the corresponding dendritic region (Fig. 4A). To identify potential VGCC types in GoC dendrites, we started out with a mixture of VGCC blockers. We chose a combination of L-, N-, and P-type blockers for several reasons: (1) these calcium channels are the most common high-voltage activated calcium channels in neurons; (2) the blockers are well characterized; and (3) the conditions for activation of these channel types are similar. The blockade of P-type ( $\omega$-agatoxin IVA, $2 \mu \mathrm{M})$, N-type $(\omega$ conotoxin GVIA, $5 \mu \mathrm{M}$ ), and L-type (nimodipine, $100 \mu \mathrm{M}$ ) VGCCs decreased the proximal calcium signal to $44 \pm 8 \%$ of control (Fig. $4 B$, left traces, and $4 E, n=7 ; p=0.016$, Wilcoxon signed-rank test), as well as broadening the action potential and decreasing the afterhyperpolarization following the action potential (see below). However, blocking P-, N-, and L-type calcium channels did not significantly alter distal calcium signals (Fig. $4 B$, right traces, and $4 E ; 85 \pm 9 \%$ of control, $p=0.44, n=8$ ) and had little effect on the action potential waveforms measured at the soma (see below). In contrast, local blockade of either R-type (SNX-482, $5 \mu \mathrm{M}$ ) or T-type (TTA-P2, $10 \mu \mathrm{M}$ ) calcium channels did not alter proximal calcium signals (Fig. $4 C$ and $4 D$, respectively, left traces, and $4 E$; for SNX-482: $103 \pm 5 \%$ of control, $n=$ $7, p=0.73$; for TTA-P2: $97 \pm 13 \%$ of control, $p=1.0$ ), but both decreased distal calcium signals by approximately half (Fig. $4 C$, right traces, and $4 E$; for SNX-482 to $55 \pm 9 \%$ of control, $n=8$, $p=0.016$; for TTA-P2 to $60 \pm 8 \%$ of control, $n=9, p=0.004$ ). These findings establish that R-type and T-type channels localize selectively to the distal dendrites, whereas some combination of

\footnotetext{
$\leftarrow$

transient amplitudes binned according to distance from soma. $E$, Two-photon image of a spontaneously active $\mathrm{GOC}_{\mathrm{C}}$ with locations of line scans indicated. $\boldsymbol{F}$, Top trace, Spontaneous action potentials recorded at the soma. Bracket indicates $0 \mathrm{mV}$ and $-60 \mathrm{mV}$. Bottom trace, Calcium signals recorded at a dendritic location indicated in $\boldsymbol{E}$. Broken line indicates $0 \mathrm{~nm}$ baseline calcium. G, Top traces, Aligned spontaneous action potentials (gray traces) and average membrane potential (black trace). Bottom, Average calcium transients in response to spontaneous action potentials recorded at locations indicated in $\boldsymbol{E}$. $\boldsymbol{H}$, Summary data of 23 cells. Binned amplitudes of calcium transients. $I$, Example traces of a $\mathrm{GOC}$ firing at different frequencies and associated dendritic calcium signals. Broken line indicates $0 \mathrm{~nm}$ baseline calcium. J, Amplitudes of dendritic baseline calcium concentration for different firing frequencies.
} 
A
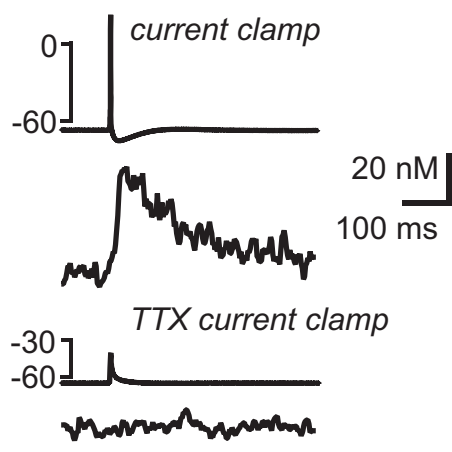

B

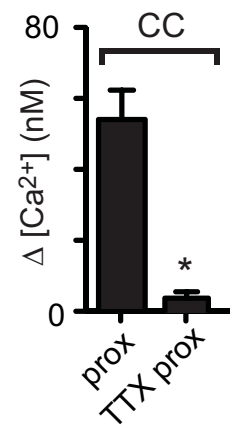

C
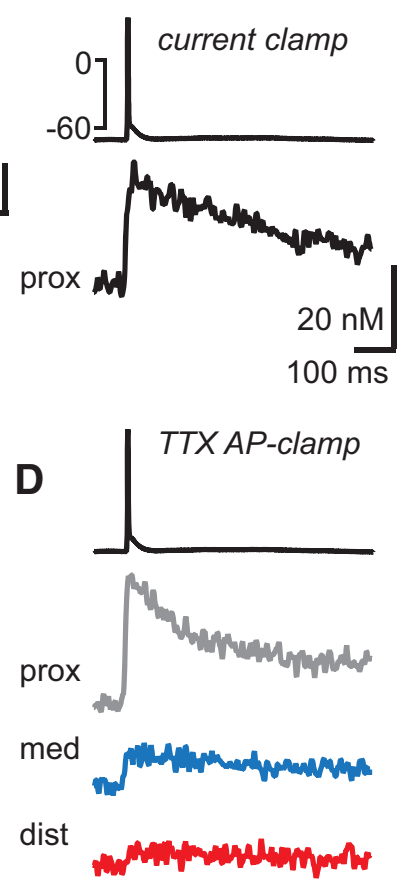

E

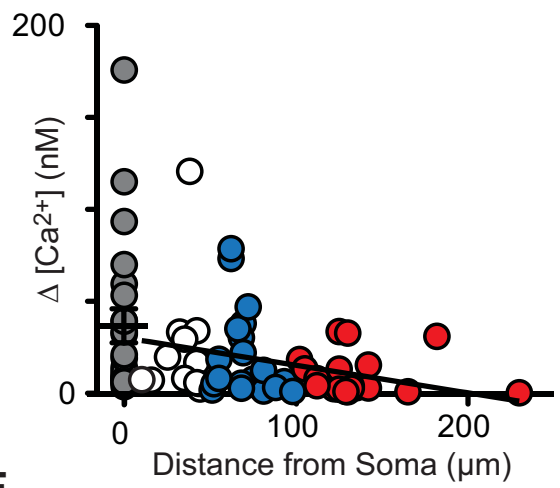

$\mathbf{F}$

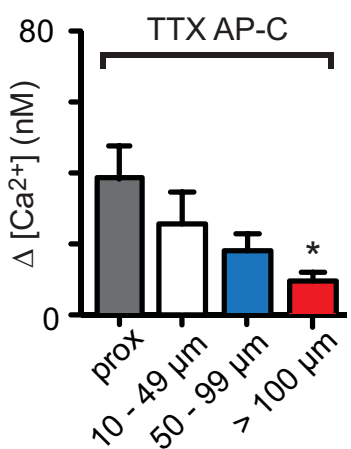

Figure 2. Dendritic sodium channels promote dendritic calcium signals. A, Top traces, The somatic action potential evokes a calcium transient in the proximal dendrite. Bottom, TTX abolishes both the action potential and the calcium signal. $\boldsymbol{B}$, Summary data of calcium signals in the presence and in the absence of TTX. $\boldsymbol{C}$, Waveform of the somatically evoked action potential in current-clamp configuration and the resulting calcium transient in the proximal dendrite. D, Top, Action potential waveform fed back to the GoC in voltage-clamp configuration in the presence of TTX. Bottom, Calcium transients measured at proximal (gray), medial ( $42 \mu \mathrm{m}$, blue), and distal (112 $\mu \mathrm{m}$, red) dendritic locations. $\boldsymbol{E}$, The amplitude of calcium transients in dependence on distance from the soma evoked in AP-clamp configuration. $\boldsymbol{F}$, Binned summary data of calcium transient amplitudes. *Denotes statistical significance.

$\mathrm{P}-, \mathrm{N}-$, and/or L-type calcium channels is present in proximal regions.

Based on the observation that both SNX-482 and TTA-P2 decrease distal calcium signals by approximately half, we hypothesized that coapplication of both blockers would completely abolish the signal. Because R- and T-type calcium channels localize selectively to the distal dendrites and have only minor effects on the somatic action potential waveforms (also see below), we bath-applied SNX-482 (1 $\mu \mathrm{M})$ and TTA-P2 $(4 \mu \mathrm{M})$. The coapplication of these antagonists did not alter the proximal calcium signal (Fig. 5A, left traces, and 5D; $96 \pm 12 \%$ of control, $n=5$, $p=0.62$, Wilcoxon signed rank test) but reduced the distal calcium signal (Fig. $5 A$, right traces, and $5 D$; to $18 \pm 4 \%$ of control, $n=10, p=0.002)$. In contrast, blocking either L- or P-type calcium channels with bath-applied nimodipine $(20 \mu \mathrm{M})$ or $\omega$-agatoxin IVA $(1 \mu \mathrm{M})$, respectively, had no effect on proximal or distal calcium transients (Fig. $5 B, D$; nimodipine: proximal $106 \pm 11 \%$ of control, $n=5, p=0.40$, distal $97 \pm 6 \%$ of control, $n=8, p=0,47$, Fig. $5 C, D ; \omega$-agatoxin IVA: proximal $111 \pm 10 \%$ of control, $n=7, p=0.55$; distal $103 \pm 11 \%$ of control, $n=14$, $p=0.99)$. These findings confirm that calcium signals in distal dendrites rely mainly on the activation of dendritic R- and T-type calcium channels, whereas L- and P-type calcium channels do not contribute to calcium signals in either proximal or distal dendrites.

In GoCs, calcium regulates the frequency and regularity of spontaneous firing by activating $\mathrm{K}_{\mathrm{Ca}}$ channels (Solinas et al., 2007; Hull et al., 2013). GoCs are typically spontaneously active, and application of the SK antagonist apamin (200 nM) increased the firing frequency to $242 \pm 59 \%$ of control $(n=6, p=0.031$, measured in regularly firing episodes; Table 1) and, in some cases, changed the regular firing pattern into a burst firing pattern that eventually resulted in depolarization block ( 3 of 6 cells). Apamin also decreased the amplitude of the afterhyperpolarization (25 \pm $1 \%$ of control, $n=6, p=0.03$, measured at $50 \mathrm{~ms}$ after the action potential peak; Fig. $6 A$; Table 1$)$, but not the action potential width ( $98 \pm 4 \%$ of control, $n=6, p=0.68$ ). The BK channel antagonist paxilline $(10 \mu \mathrm{M})$ also significantly increased the firing frequency (to $213 \pm 39 \%$ of control, $n=9, p=0.019$; Table 1) and decreased the afterhyperpolarization $(83 \pm 9 \%$ of control, $n=9 ; p=0.008$ Fig. $6 B$; Table 1$)$. In addition, paxilline increased the width of the action potential $(119 \pm 13 \%$ of control, $n=9$, $p=0.027$; Table 1). $\mathrm{K}_{\mathrm{Ca}}$ channels are sometimes opened by closely associated calcium channels (Lancaster and Nicoll, 1987; Berkefeld et al., 2006; Engbers et al., 2012) and, in other instances, by VGCCs that are more loosely coupled (Alle et al., 2011; Jones and Stuart, 2013). To determine the roles of different types of VGCCs in spontaneous firing by regulation of $\mathrm{K}_{\mathrm{Ca}}$ channels, we applied specific calcium channel blockers. Inhibition of N-type calcium channels doubled firing frequency (to $200 \pm 33 \%$ of control, $n=12, p=0.0005$; Fig. $6 G$; Table 1), and in a subset of cells resulted in a transition to burst firing and/or depolarization block ( 7 of 12 cells; Fig. 6C). Importantly, N-type channel inhibition also increased action potential width (123 $\pm 13 \%$ of control, $n=11, p=0.001$; Fig. $6 H$; Table 1$)$ and strongly decreased afterhyperpolarization $(53 \pm 6 \%$ of control, $n=11, p=0.001$; Fig. $6 I)$. The effect of $\omega$-conotoxin GVIA $(2 \mu \mathrm{M})$ on action potential width resembled the effect on BK channel inhibition with paxilline, whereas the effect on afterhyperpolarization and firing pattern resembled inhibition of SK channels with apamin. Con- 
A

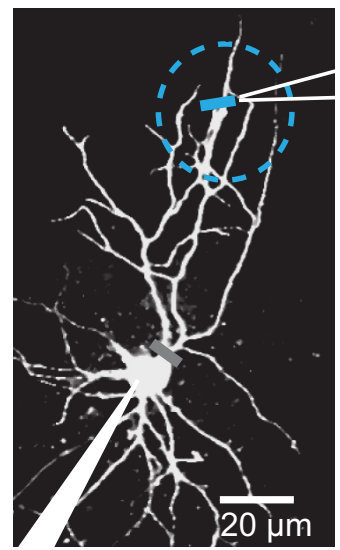

D

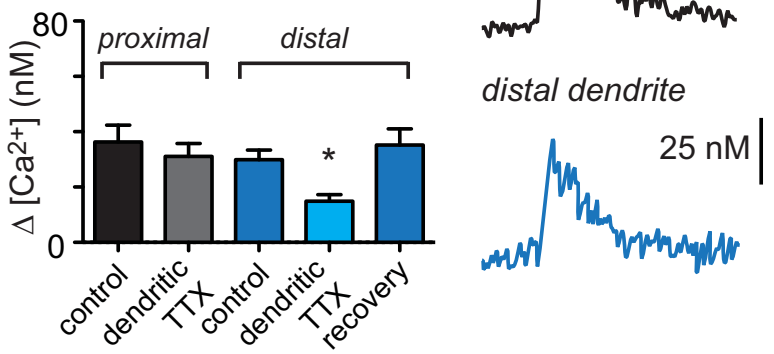

B

proximal $A P$

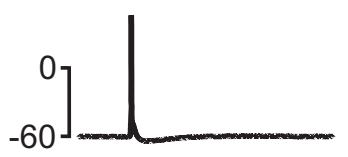

proximal dendrite

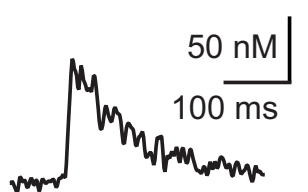

distal dendrite

distal dendrite

+ dendritic TTX

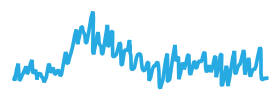

Figure 3. Local inhibition of dendritic sodium channels attenuates dendritic calcium signals. $A$, Schematic of the experimental setup. Action potentials are evoked somatically, whereas calcium transients are recorded at a proximal and a distal dendritic location. The puff pipette (white lines) is placed near the distal dendrite, and TTX is applied locally (cyan dashed circle). B, Somatically evoked action potential, proximal calcium transient (black), and distal calcium transient (recorded $\sim 72 \mu \mathrm{m}$ from soma, blue). C, Somatic action potential during dendritic TTX application, proximal calcium transient (gray), and distal calcium transient (cyan). D, Summary data of calcium signals. *Denotes statistical significance.

versely, the blockade of either L-type (Fig. 6D) or P-type calcium channels (Fig. $6 E$ ) or the blockade of P-type (Fig. $6 E$ ) or R-type and T-type calcium channels (Fig. $6 F$ ) had little, if any, effect on the firing frequency (L-type: $114.8 \pm 10.8 \%$ of control, $n=7, p=$ 0.23; P-type: $94.2 \pm 7.8 \%$ of control, $n=7, p=0.47$; R/T-type: $128.3 \pm 13.1 \%, n=16, p=0.01$; Table 1$)$, the action potential width (L-type: $101 \pm 1 \%$ of control, $n=7, p=0.81$; P-type: $103 \pm 2 \%$ of control, $n=7, p=0.22$, R/T-type: $108 \pm 4 \%$ of control, $n=16, p=0.073$; Table 1), or the afterhyperpolarization (L-type: $95 \pm 3 \%$ of control, $n=7, p=0.16$; P-type: $99 \pm 6 \%$ of control, $n=7, p=0.69$; R/T-type: $85 \pm 5 \%$ of control, $n=16$, $p=0.02$; Fig. $6 G, H$; Table 1 ). These findings suggest that $\mathrm{N}$-type calcium channels located near the soma are the primary calcium source that controls action potential width, afterhyperpolarization, and the frequency and regularity of spontaneous firing, whereas the effect of R- and T-type channel blockade on action potential firing and afterhyperpolarization is small. The lack of effect on action potential width suggests that T- and/or R-type channels do not signal to low-affinity BK channels in GoCs.

Because endogenous calcium-binding proteins control calcium signaling and calcium-activated processes in cells (Schwaller, 2010; Eggermann et al., 2012; Matthews and Dietrich, 2015), including the interaction of VGCCs with target proteins, we next investigated calcium dynamics in GoCs. The types and concentrations of calcium binding proteins in GoCs are not known, although it is recognized that they lack the classic calcium binding proteins parvalbumin, calbindin, and calretinin that are present at high concentrations in many types of interneurons (Geurts et al., 2001; Simat et al., 2007). Because the level of calcium-binding proteins can spatially restrict the spread of calcium within a cell (Goldberg et al., 2003; Soler-Llavina and Saba- tini, 2006) and can decrease the amplitude and/or prolong the decay of bulk calcium levels (Lee et al., 2000; Aponte et al., 2008), it is important to determine the endogenous buffer capacity in GoCs. We took advantage of a widely used method (Neher and Augustine, 1992; Helmchen et al., 1996; Maravall et al., 2000; Sabatini et al., 2002; Brenowitz and Regehr, 2007) in which action potential-evoked calcium increases are monitored while a calcium indicator $(200 \mu \mathrm{M}$ Fluo-5F) along with a red calcium-insensitive dye (10 $\mu \mathrm{M}$ Alexa 594) fills the cell to increase the total buffer capacity (Fig. 7A). Dye loading was monitored at the proximal dendrite shortly after break-in (within $\sim 30-45$ s) until full equilibration of the dye was achieved (typically $\sim 40 \mathrm{~min}$ ). Added buffer capacity, $\kappa_{\text {ind }}$, was calculated as previously described (Brenowitz and Regehr, $2007)$, with $\kappa_{\text {ind }}=[$ Fluo $-5 F](t) / K_{d}$, [Fluo-5F] $(\mathrm{t})=\left(\mathrm{R}(\mathrm{t}) / \mathrm{R}_{\max }\right)[\text { Fluo } 5 \mathrm{~F}]_{\mathrm{pi}^{-}}$ pette, where $[$ Fluo $-5 \mathrm{~F}](\mathrm{t})$ and $\mathrm{R}(\mathrm{t})$ are the indicator concentration and the Alexa 594 fluorescence intensity at time $t$, respectively, $\mathrm{K}_{\mathrm{d}}$ is the dissociation constant of the indicator, and $[\text { Fluo- } 5 \mathrm{~F}]_{\text {pipette }}(\mathrm{t})$ and $\mathrm{R}_{\text {pipette }}(\mathrm{t})$ are the indicator concentration and the intensity of Alexa 594 at time $\mathrm{R}_{\max }$ the intensity at steady state. Figure $7 B$ shows a typical experiment in which $\kappa_{\text {ind }}$ continuously increases, resulting in a decrease in the action potential-evoked calcium signal $\Delta\left[\mathrm{Ca}^{2+}\right]$. As $\kappa_{\text {ind }}$ increases, the action potential evoked calcium transients that become smaller and slower (Fig. $7 C$ ). A plot of $1 / \Delta\left[\mathrm{Ca}^{2+}\right]$ versus $\kappa_{\text {ind }}$ is fit with a line and extrapolated to determine the peak calcium transient in the absence of added buffer $\left(\Delta\left[\mathrm{Ca}^{2+}\right]_{0}\right.$, the $y$-intercept, which is $183 \mathrm{nM}$ for this cell), and the endogenous buffer capacity in the absence of added buffer ( $\kappa_{0}$, the $x$-intercept, which is 44 for this cell; Fig. $7 D)$. The average $\Delta\left[\mathrm{Ca}^{2+}\right]_{0}$ was $143 \pm 23 \mathrm{~nm}$ in GoCs (range 55-295 nM, $n=10$; Fig. $7 E$ ) and $\kappa_{0}$ was $66 \pm 9$ (range 38-117; Fig. 7E), which is low compared with many other interneurons (see Discussion). Because intracellular calcium buffers bind free calcium and thereby can decrease the peak of the calcium transient, this low buffer capacity allows even a modest density of VGCCs to produce large increases in calcium (see Discussion). Importantly, to ensure that calcium influx remains constant over the course of the experiment, we also determined action potential width shortly after and $20 \mathrm{~min}$ after breaking into the cell. Action potential width did not change after introduction of Fluo-5F $(0.62 \pm 0.05 \mathrm{~ms}$ and $0.66 \pm 0.06 \mathrm{~ms}, n=10 ; p=0.074$, paired $t$ test).

Another important aspect of calcium signaling in GoCs is the proximity of calcium channels to $\mathrm{K}_{\mathrm{Ca}}$ channels. The ability of GoCs to fire spontaneously and regularly requires calcium entry through N-type calcium channels to activate $\mathrm{K}_{\mathrm{Ca}}$ channels (Fig. 6). In other types of neurons, the interaction between VGCCs and calcium-dependent activation of potassium channels requires a close spatial relationship, so-called nanodomains or microdomains (Lancaster and Nicoll, 1987; Marrion and Tavalin, 1998; Ngo-Anh et al., 2005; Fakler and Adelman, 2008; Jones and Stuart, 2013). One way of probing the distance between N-type cal- 


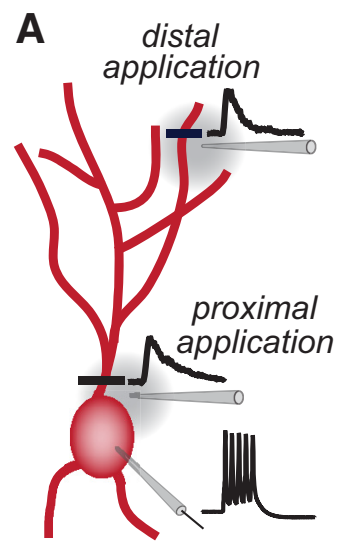

$$
\begin{aligned}
& \text { B apply + measure } \\
& \text { proximal distal }
\end{aligned}
$$

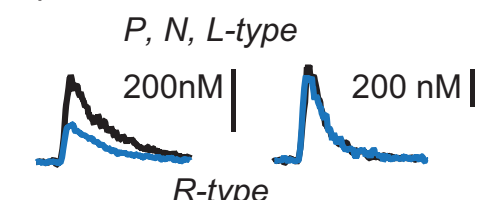

R-type
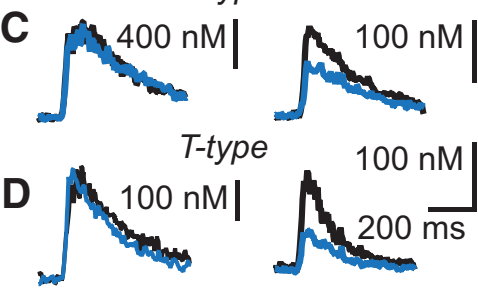

E

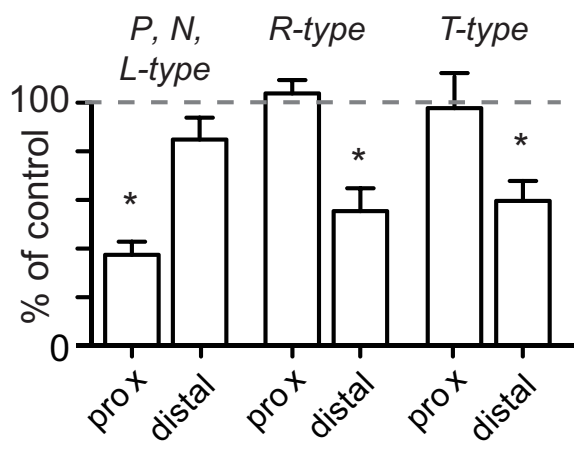

Figure 4. Different calcium channels mediate proximal and distal calcium transients. $\boldsymbol{A}$, Schematic of experiment. Bursts of action potentials are evoked somatically. Calcium transients are recorded at a proximal and a distal location; specific calcium channel antagonists are applied locally. $\boldsymbol{B}-\boldsymbol{D}$, Calcium transients in the presence and absence of calcium channel antagonists applied to the proximal and distal dendrites. $\boldsymbol{B}$, Antagonists of P-type ( $\omega$-agatoxin IVA), $\mathrm{N}$-type ( $\omega$-conotoxin GVIA), and L-type (nimodipine) channels were coapplied. C, Calcium transients in the presence and absence of the R-type channel antagonist SNX-482. D, Application of the T-type channel antagonist TTA-P2. $\boldsymbol{E}$, Summary data of calcium channel pharmacology. *Denotes statistical significance.

cium channels and $\mathrm{K}_{\mathrm{Ca}}$ channels is to introduce exogenous buffers. If high concentrations of fast calcium buffers, such as BAPTA, are required to prevent calcium activation of channels, then the coupling distance between $\mathrm{N}$-type calcium channels and $\mathrm{K}_{\mathrm{Ca}}$ channels is predicted to be short (Adler et al., 1991). Surprisingly, we found that low BAPTA concentrations $(1 \mathrm{~mm})$ had no effect on action potential frequency $(5.2 \pm 0.4 \mathrm{~Hz}$ to $5.5 \pm 0.7 \mathrm{~Hz}, n=11, p=$ 0.23 ; Fig. $8 A, D$; Table 2 ), and only minor effects on action potential width (113 $\pm 5 \%$ of control, $n=11, p=0.013$; Fig. $8 A$, $E$; Table 2$)$ and afterhyperpolarization ( $87 \pm 4 \%$ of control, $n=11, p=0.009$; Fig. $8 A, F)$, whereas higher concentrations $(10 \mathrm{~mm})$ resulted in a pronounced increase in action potential frequency $(273 \pm 28 \%$ of control, $n=4, p=0.002$; Fig. $8 B, D$; Table 2), bursting, an increase in action potential width $(156 \pm 8 \%, n=4, p=0.004$, Fig. $8 B, E)$ and a decrease in afterhyperpolarization (reduced to $14 \pm 6 \%$ of control, $n=4, p=0.003$; Fig. $8 B, F)$. High concentrations ( $10 \mathrm{~mm})$ of the slow buffer EGTA, however, had no significant effect on action potential frequency $(5.2 \pm 0.6 \mathrm{~Hz}$ to $6.7 \pm 1.3 \mathrm{~Hz}, n=9, p=0.11$; Fig. $8 C, D)$, and only a minor effect on afterhyperpolarization $(81 \pm$ $9 \%, n=9, p=0.02$; Fig. $8 C, E)$ and width $(118 \pm 4 \%, n=9, p=$ 0.013 ; Fig. $8 C, F)$, suggesting that the majority of VGCCs are closely coupled to $\mathrm{K}_{\mathrm{Ca}}$ channels (Fig. 6).

It is possible to estimate the distance between VGCCs and $\mathrm{K}_{\mathrm{Ca}}$ channels as distance $=\left(\mathrm{D}_{\mathrm{Ca}} / \mathrm{k}_{\mathrm{o}}[\text { buffer }]\right)^{1 / 2}$, where $[$ buffer $]$ is the
A proximal distal

\section{R-type + T-type channel antagonists}

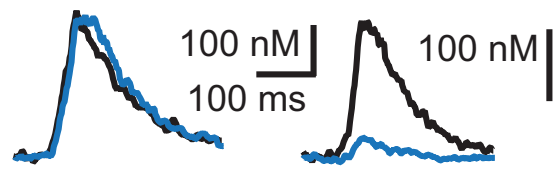

B L-type channel antagonist

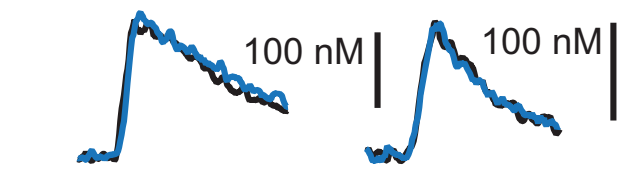

C P-type channel antagonist
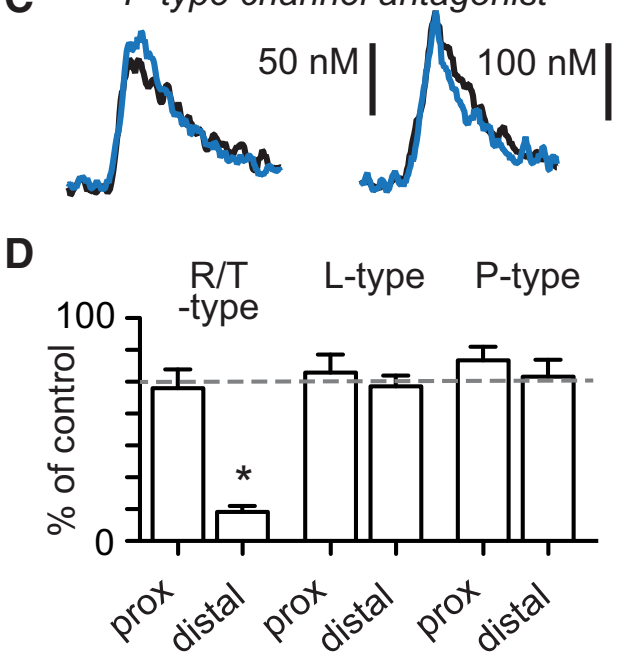

Figure 5. Bath application of R-type and T-type but not L-type or P-type channel blockers suppresses dendritic calcium signals. $A$, Coapplication of R-type and T-type channel antagonists does not affect the proximal calcium transient but diminishes the distal dendritic calcium transient. $\boldsymbol{B}$, Block of L-type calcium channels or (C) P-type calcium channels has no effect on the amplitude of the proximal and distal calcium transients. $\boldsymbol{D}$, Summary data of the effect of calcium channel antagonists on the amplitude of dendritic calcium signals. *Denotes statistical significance.

buffer concentration, $\mathrm{D}_{\mathrm{Ca}}$ is the diffusion coefficient for calcium $\left(2.2 \times 10^{-10} \mathrm{~m}^{2} \mathrm{~s}^{-1}\right)$, and $\mathrm{k}_{0}$ is the binding rate of the added buffer, which is $4 \times 10^{8} \mathrm{M}^{-1} \mathrm{~s}^{-1}$ for BAPTA and $1 \times 10^{7}$ $\mathrm{M}^{-1} \mathrm{~s}^{-1}$ for EGTA. We estimate that the distance between $\mathrm{N}$-type calcium channels and $\mathrm{K}_{\mathrm{Ca}}$ channels is $<20 \mathrm{~nm}$ (predicted distance for $1 \mathrm{~mm}$ BAPTA $=\sim 23 \mathrm{~nm}$ ), given the small effect of 1 mM BAPTA and $10 \mathrm{~mm}$ EGTA, the lack of effect of $200 \mu \mathrm{M}$ Fluo-5F (Fig. 7), and the strong effect of $10 \mu \mathrm{M}$ BAPTA on spontaneous firing and action potential waveform.

The observation that VGCC types in GoCs are segregated suggests that they carry location-specific functional roles. We have established that $\mathrm{N}$-type calcium channels near the soma are essential to regulating GoC output. We next examined the functional role of VGCCs expressed in GoC dendrites. T-type calcium channels, which we found are localized to distal GoC dendrites (Figs. 4, 5), have been implicated in burst firing in many types of neurons (Huguenard and Prince, 1992; Molineux et al., 2006; Pressler et al., 2013). To test whether T-type channels in GoCs can contribute to rebound bursting, we allowed GoCs to fire spontaneous action potentials, and then hyperpolarized the cells for $500 \mathrm{~ms}$ to $-84 \pm 3 \mathrm{mV}(n=19)$ to relieve inactivation of T-type calcium channels. Returning the cells to their resting membrane potential led 
Table 1. Action potential properties: potassium channel and calcium channel antagonists

\begin{tabular}{|c|c|c|c|c|c|c|}
\hline & Control/SK-type & Control/BK-type & Control/N-type & Control/L-type & Control/R/T-type & Control/P-type \\
\hline \multirow[t]{2}{*}{ Frequency (Hz) } & $6.4 \pm 0.8$ & $3.6 \pm 0.6$ & $5.7 \pm 0.7$ & $7.4 \pm 1.2$ & $6.4 \pm 0.5$ & $7.1 \pm 1.5$ \\
\hline & $15.5 \pm 3.7$ & $6.2 \pm 0.6$ & $10.9 \pm 1.7$ & $8.1 \pm 1.1$ & $7.8 \pm 0.6$ & $6.1 \pm 1.0$ \\
\hline \multirow[t]{2}{*}{ AP width (ms) } & $0.60 \pm 0.04$ & $0.81 \pm 0.02$ & $0.60 \pm 0.03$ & $0.51 \pm 0.04$ & $0.70 \pm 0.06$ & $0.60 \pm 0.05$ \\
\hline & $0.60 \pm 0.05$ & $0.96 \pm 0.05$ & $0.76 \pm 0.07$ & $0.51 \pm 0.05$ & $0.77 \pm 0.07$ & $0.60 \pm 0.05$ \\
\hline \multirow[t]{2}{*}{$\operatorname{AHP}(\mathrm{mV})$} & $8.8 \pm 1.0$ & $9.1 \pm 0.6$ & $11.8 \pm 0.7$ & $11.2 \pm 1.1$ & $13.5 \pm 0.7$ & $11.8 \pm 0.8$ \\
\hline & $2.2 \pm 0.6$ & $8.0 \pm 0.7$ & $6.3 \pm 0.8$ & $10.6 \pm 1.1$ & $11.2 \pm 0.6$ & $11.5 \pm 0.8$ \\
\hline
\end{tabular}

A

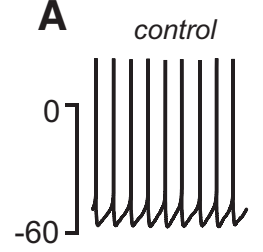

B

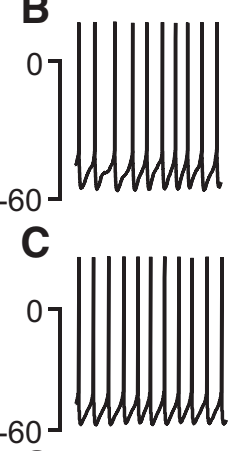

G
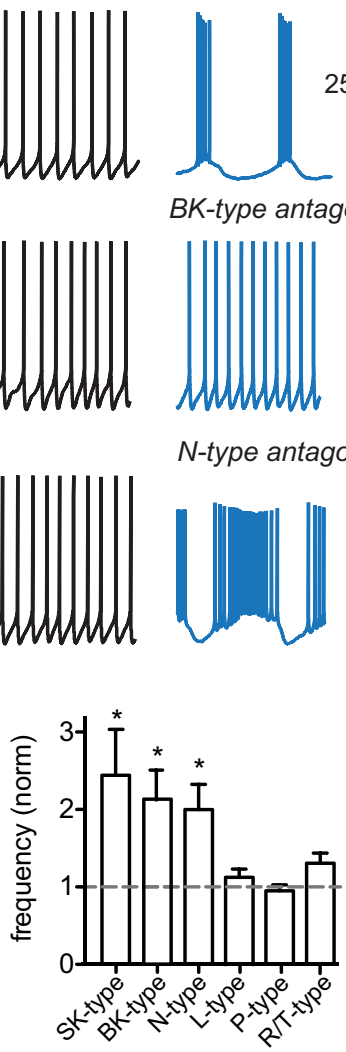

SK-type antagonist

BK-type antagonist

N-type antagonist
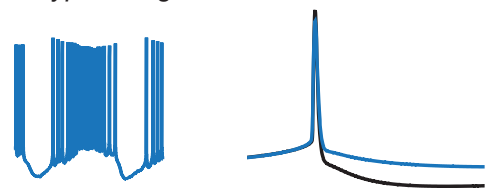

H

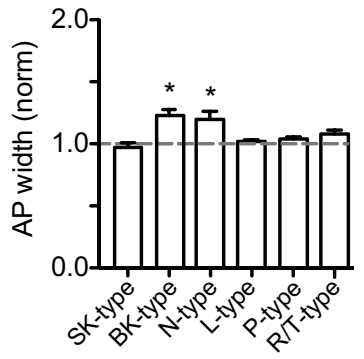

L-type antagonist
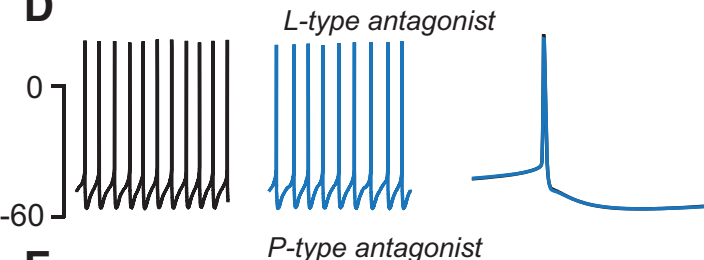

P-type antagonist
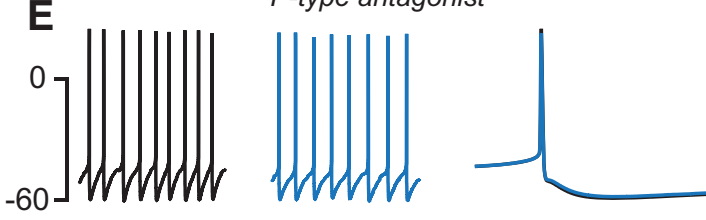

$R$ - and T-type antagonist
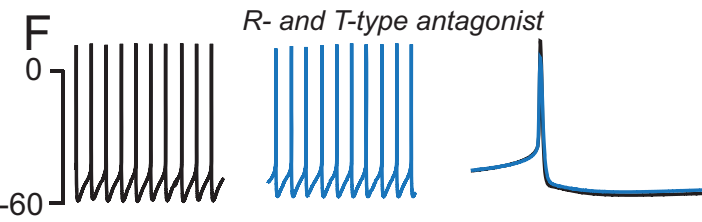

I

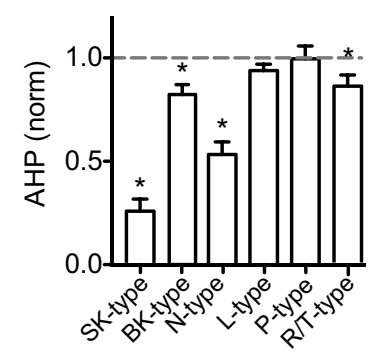

Figure 6. The effect of calcium-dependent potassium channel and calcium channel inhibition on Golgi cell firing. $\boldsymbol{A}$, Spontaneously firing GoC in the absence (black trace, left) or in the presence of the SK-type potassium channel blocker apamin (blue trace, right). B, Same experiment but blue trace in the presence of the BK-type potassium channel blocker paxilline. $C$, The N-type channel blocker $\omega$-conotoxin GVIA. D, The L-type calcium channel antagonist nimodipine. $\boldsymbol{E}$, The P-type calcium channel blocker $\omega$-agatoxin IVA. $\boldsymbol{F}$, The R-type and T-type channel blockers SNX-482 and TTA-P2, respectively. $\mathbf{G}$, Summary data of action potential frequency. $\boldsymbol{H}$, Action potential (AP) width. $\boldsymbol{I}$, Afterhyperpolarization (AHP). *Denotes statistical significance.

to a transient increase in firing frequency (to $166 \pm 14 \%$ of control, range $106 \%-344 \%$, from $6.5 \pm 0.9 \mathrm{~Hz}$ at baseline measured for several seconds before the hyperpolarizing step to $9.7 \pm 1.2 \mathrm{~Hz}$ measured during the $500 \mathrm{~ms}$ following the pulse, $n=19, p=0.0001$; Fig. $9 A)$. TTA-P2 strongly attenuated this increase in firing frequency (112 $\pm 6 \%$, range $99 \%-131 \%$, from $6.1 \pm 1.1 \mathrm{~Hz}$ at baseline, to $6.7 \pm 1.1 \mathrm{~Hz}, n=9, p=0.04$; Fig. 9B), indicating that it was mediated primarily by T-type calcium channels. The variability in the extent of bursting we observed could be explained by differences in T-type channel availability and some heterogeneity in VGCC expression within the GoC population. Figure $9 C$ shows the cumulative probability histogram of the ratio of the posthyperpolarization firing frequency (frequency burst $_{\text {) }}$ ) divided by the baseline firing frequency before hyperpolarization (frequency ${ }_{\text {pre }}, n=19$; black trace) and in the presence of TTA-P2 $(n=9$, blue trace, $p<0.001$, Kolmogorov-Smirnov test). We also tested whether dendritic calcium channels influence the integration of grc inputs onto distal GoC dendrites. Because transmitter release at parallel fiber terminals par- tially depends on R-type calcium channels (Mintz et al., 1995), we limited our investigation to T-type channels. We found that TTA-P2 did not affect synaptic responses (parallel fiber EPSC in TTA-P2 was $107 \pm 13 \%$ of control, $n=6, p=0.84$, paired-pulse ratio was $97 \pm$ $10 \%$ of control, $n=6, p=0.57$, paired $t$ test, data not shown). In current clamp, we hyperpolarized GoCs to $\sim-65 \mathrm{mV}$ to prevent spontaneous spiking and then evoked parallel fiber EPSPs by placing a stimulus electrode in the molecular layer of the cerebellar cortex. We found that, when no inhibitor was applied, the EPSP amplitude remained constant over time $(102.2 \pm 6.2 \%$ of control, $n=10, p=$ 0.64; Fig. 9D). Conversely, inhibition of T-type calcium channels reduced the EPSP amplitude to $80.7 \pm 7.8 \%$ of control $(n=19, p=$ 0.007; Fig. $9 E$; cumulative probability histogram of the ratio of EPSP amplitudes at the indicated time points, $p<0.001$, KolmogorovSmirnov test; Fig. 9F). These data suggest that T-type calcium channels located in distal GoC dendrites can boost synaptic inputs from grcs onto GoCs. 
A
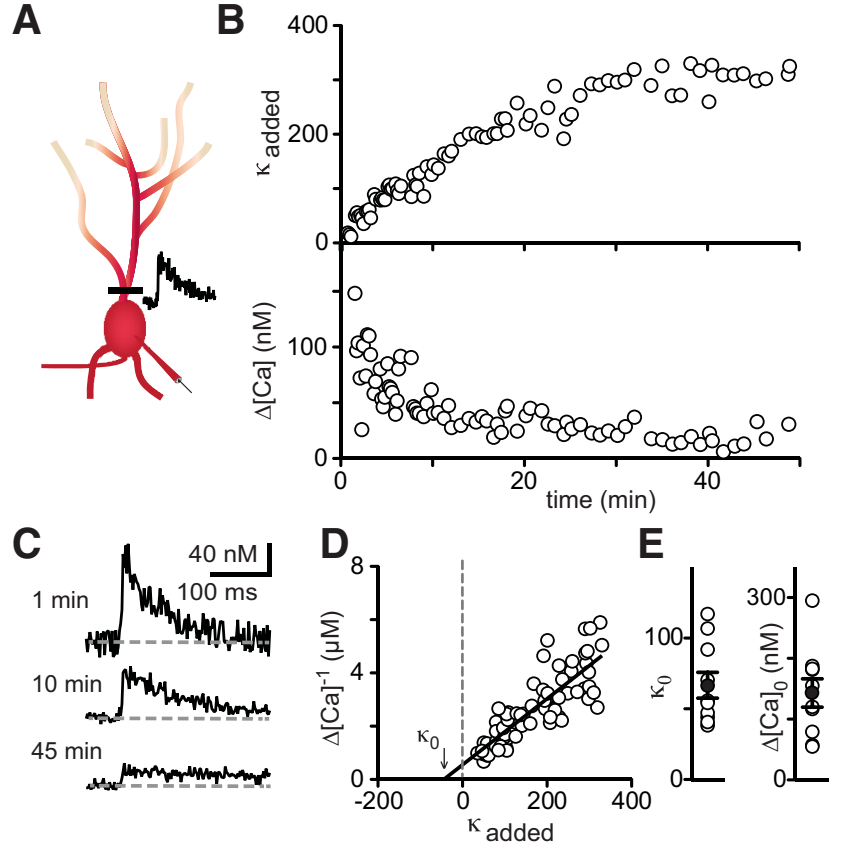

Figure 7. Low endogenous calcium buffer capacity in Golgi cells. $\boldsymbol{A}$, Schematic showing experimental setup for measuring calcium buffer capacity. Action potential-evoked calcium transients are measured continuously at a proximal dendritic site until the calcium-insensitive red dye has equilibrated. $\boldsymbol{B}$, Top, Added buffer capacity. Bottom, Peak calcium concentration in response to a single action potential during loading of the cell with Alexa 594 and Fluo-5F. C, Calcium transients recorded at time points indicated. $\boldsymbol{D}$, Relationship between $\Delta\left[\mathrm{Ca}^{2+}\right]^{-1}$ and added buffer capacity $\kappa$ during dye loading. Arrow indicates endogenous buffer capacity. $\boldsymbol{E}$, Summary data of endogenous buffer capacity and amplitude of the calcium signal in the absence of exogenous buffer.

\section{Discussion}

Here we report that differential distribution of various types of VGCCs within GoCs leads to functional compartmentalization. To our surprise, we found that $\mathrm{GoC}$ dendrites are electrically active and that voltage-gated sodium channels help to activate the $\mathrm{R}$ - and T-type calcium channels that are present in distal dendrites but absent near the soma. Dendritic T-type channels mediate rebound bursting and boost synaptic inputs from grcs, thereby amplifying feedback inhibition ( $\mathrm{grc} \rightarrow \mathrm{GoC} \rightarrow \mathrm{grc}$ ). In contrast, N-type calcium channels are absent from distal dendrites but are present near the soma where they control the opening of $\mathrm{K}_{\mathrm{Ca}}$ channels and thereby regulate spontaneous firing.

\section{Active dendrites in GoCs}

Counter to previous results, we find that that $\mathrm{GoC}$ dendrites are active and contain both voltage-gated sodium and calcium channels that allow somatic depolarization to propagate along the entire length of $\mathrm{GoC}$ dendrites to enable calcium influx (Fig. 1). It is likely that the fragile nature of GoCs, coupled with low calcium channel density, hampered the detection of active dendritic properties. For example, even modest dendritic depolarization can inactivate low voltage-activated T-type calcium channels. Moreover, low channel density complicated the optical detection of dendritic calcium signals, which were strongly attenuated when using typical concentrations of calcium indicator $(\sim 100-$ $200 \mu \mathrm{M}$ ). We thus limited our experiments to spontaneously active GoCs and used low calcium indicator concentrations.

Active dendrites provide diverse functions in many neuronal cell types, including interneurons (Goldberg and Yuste, 2005), and we have begun to examine some of the possible roles of dendritic ion
A
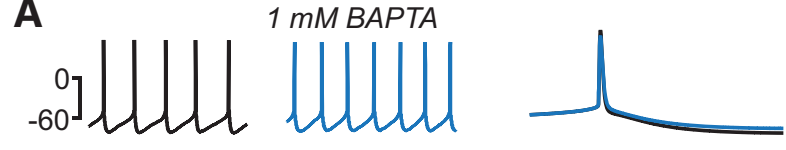

B

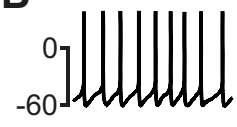

10 mM BAPTA

C

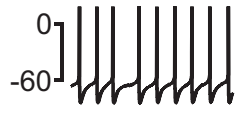

D

E

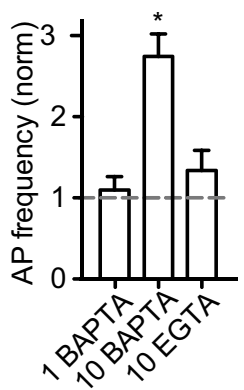

$\mathbf{F}$

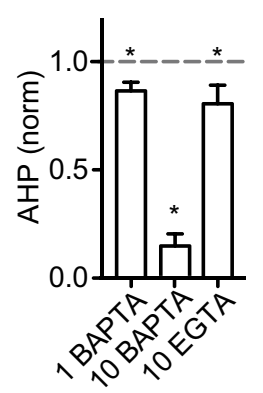

Figure 8. The effect of exogenous calcium buffers on firing pattern and action potential waveform in Golgi cells. $\boldsymbol{A}$-C. Left, Spontaneous action potentials directly after break-in (black traces) and after introduction of the indicated concentrations of exogenous buffer (blue traces). Right, Average action potentials on an expanded time scale. $\boldsymbol{D}$, Normalized action potential firing rate (left). $\boldsymbol{E}$, Action potential width. $\boldsymbol{F}$, Afterhyperpolarization after introduction of exogenous buffers. *Denotes statistical significance.

Table 2. Action potential properties: calcium buffers

\begin{tabular}{lccc}
\hline & Control/10 BAPTA & Control/1 BAPTA & Control/10 EGTA \\
\hline Frequency (Hz) & $7.4 \pm 0.9$ & $5.2 \pm 0.4$ & $5.2 \pm 0.6$ \\
& $19.8 \pm 1.5$ & $5.5 \pm 0.7$ & $6.7 \pm 1.3$ \\
AP width (ms) & $0.73 \pm 0.06$ & $0.89 \pm 0.03$ & $0.74 \pm 0.02$ \\
& $1.13 \pm 0.10$ & $1.00 \pm 0.03$ & $0.87 \pm 0.04$ \\
AHP $(\mathrm{mV})$ & $7.8 \pm 1.0$ & $13.8 \pm 0.5$ & $12.5 \pm 1.4$ \\
& $0.2 \pm 0.9$ & $11.9 \pm 0.4$ & $9.8 \pm 1.2$ \\
\hline
\end{tabular}

channels in GoCs. GoC activity depends on both the intrinsic properties of GoCs and the excitation they receive from synaptic input onto their dendrites. However, assuming GoC dendrites are passive, synaptic input to distal dendrites would be ineffective at driving firing due to passive attenuation. In pyramidal neurons, differentially distributed voltage-dependent conductances produce active dendrites that compensate for this spatial handicap and selectively strengthen distal synaptic inputs (Branco and Häusser, 2011), but little is known whether interneurons use similar strategies. In GoC dendrites, T-type calcium channels might enhance parallel fiber inputs to distal apical dendrites, allowing distal voltage signals to propagate to the soma and increasing the likelihood of evoking an action potential. T-type calcium channels in GoCs also promote rebound burst firing. Similar burst firing occurs in other types of neurons and contributes to synaptic plasticity and rhythmic activity during certain behavioral states (Aizenman et al., 1998; Williams and Stuart, 1999; Cueni et al., 2008; Coulon et al., 2009; Errington et al., 2010). GoCs exhibit bursts of activity in vivo during certain behaviors (Heine et al., 2010), but the mechanism underlying this bursting is unknown. In order for T-type calcium channels to be available to promote bursting, neurons must be hyperpolarized. In GoCs, this 
A

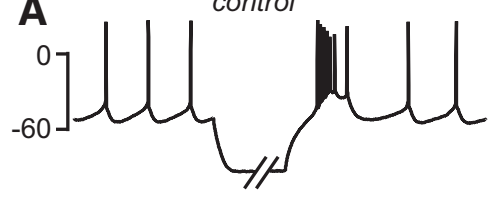

$\overline{250 \mathrm{~ms}}$

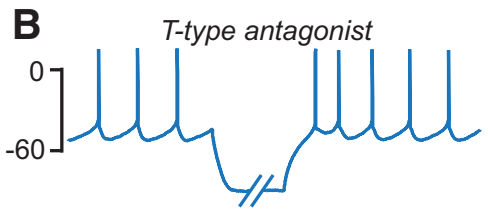

C

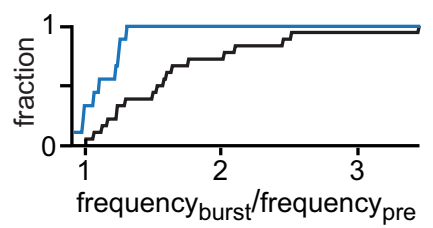

D

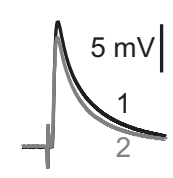

E

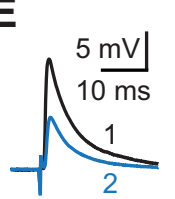

$\mathbf{F}$

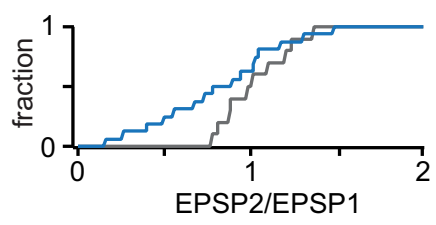

Figure 9. Dendritic T-type calcium channels promote burst firing and boost parallel fiber input to Golgi cells. $A$, Rebound burst firing following hyperpolarization of a spontaneously active GoC (black trace). B, The T-type channel antagonist TTA-P2 decreases rebound bursting (blue trace). $C$, Cumulative probability histogram of the ratio of burst and prehyperpolarization action potential frequency (frequ burst $_{\text {frequ }}$ pre) before (black trace) and after TTA-P2 application (blue trace). D, PF-EPSPs (left, black and gray trace) recorded at the time points indicated (right graphs) in the absence of the T-type channel antagonist. E, PF-EPSPs before (left, black trace) and after TTA-P2 application (blue trace). Inhibition of T-type calcium channels decreases PF-EPSP amplitude in a representative experiment (right). $\boldsymbol{F}$, Cumulative probability histogram of the EPSP2/EPSP1 ratio: gray trace represents ACSF control; blue trace represents TTA-P2 application.

could be accomplished by inhibition from other GoCs (Hull and Regehr, 2012) and Lugaro cells (Dieudonné and Dumoulin, 2000), or by activation of metabotropic receptors such as mGluR2 receptors following parallel fiber activity (Watanabe and Nakanishi, 2003). Therefore, T-type channel activation in GoC dendrites could depend strongly on network state.

Active dendrites in electrically coupled neurons can contribute to synchronous activity (Bennett and Zukin, 2004; Connors and Long, 2004). GoC dendrites express gap junctions and display synchronous spiking (Dugué et al., 2009). We speculate that synchrony of GoCs could be facilitated by (1) propagation of somatic action potentials to the gap junctions on dendrites, and (2) calciumdependent local boosting of afterhyperpolarization by activation of dendritic $\mathrm{K}_{\mathrm{Ca}}$ channels, as described in other neurons (Cueni et al., 2008; Ohtsuki et al., 2012; Jones and Stuart, 2013). We also propose that boosting of distal synaptic input by T-type channels could further enhance depolarization of neighboring coupled GoC dendrites.

There are many additional potential roles of active dendrites in GoCs that have yet to be explored. More specifically, the function of R-type calcium channels in GoC dendrites is unknown. Because of their distinct properties, the conditions for activation and the functions of R-type and T-type calcium channels are predicted to differ considerably. As observed in other neurons, dendritic R-type calcium channels could locally regulate calcium-dependent processes, such as control of excitability, synaptic strength, and dendritic release of chemical messengers (Bloodgood and Sabatini, 2007; Jones and Stuart, 2013). It will therefore be interesting to investigate the physiological significance of active GoC dendrites in more detail.

\section{A comparison of $\mathrm{GoC}$ dendrites to other interneurons}

Much is known about active dendrites in large excitatory neurons (Johnston et al., 1996; Major et al., 2013), but functional and anatomical heterogeneity has precluded a general conclusion on dendrite properties in interneurons. A uniformly high density of sodium channels was found in dendrites of hippocampal somatostatin interneurons (Martina et al., 2000), whereas a gradient of sodium and potassium channel expression prevailed in fast spiking parvalbumin interneurons ( $\mathrm{Hu}$ et al., 2010). Additional studies reported active dendrites in other cortical (Goldberg et al., 2004; Kaiser et al., 2004), hippocampal (Rózsa et al., 2004; Evstratova et al., 2011), and thalamic (Acuna-Goycolea et al., 2008; Casale and McCormick, 2011) interneurons. GoC dendrites are therefore not unusual in that they express diverse voltage-dependention channels. Indeed, small electrically compact interneurons of the cerebellar cortex are some of the few interneuron types that promote dendritic action potential-dependent calcium signals despite the lack of dendritic sodium channels (Myoga et al., 2009) but integrate distal synaptic inputs with considerable sublinearity (Abrahamsson et al., 2012).

A comparison of calcium signaling in GoCs and other interneurons also reveals significant differences. We find that action potentials elevate calcium by $\sim 140 \mathrm{~nm}$ in the absence of exogenous buffers (Fig. 7) in GoCs, compared with $40 \mathrm{~nm}$ for hippocampal fast spiking interneurons (Aponte et al., 2008) and $\sim 140 \mathrm{~nm}$ for cortical bitufted interneurons (Kaiser et al., 2001). The reasonably large calcium increases in GoCs are in part a consequence of their low buffer capacity $(\sim 66)$, which is substantially lower than that of hippocampal fast spiking interneurons $(\sim 200)$, and cortical bitufted interneurons $(\sim 285)$. For dendrites of comparable diameters, an estimate of the relative calcium influx per action potential $\left(\mathrm{Ca}_{\text {influx }}\right)$ is proportional to $\left(\Delta\left[\mathrm{Ca}^{2+}\right]_{0} /\right.$ $\left.\kappa_{0}\right)$. Thus, single action potentials evoke calcium signals in GoCs that are comparable in size to those in cortical bitufted interneurons, but $\kappa_{0}$ and $\mathrm{Ca}_{\text {influx }}$ (and calcium channel density) are smaller by a factor of 4 in GoCs. This suggests that, in GoCs, a modest density of calcium channels can produce large calcium increases because their buffer capacity is low. We hypothesize that the low calcium buffer capacity of GoCs likely contributes to their fragility. GoCs are exceptionally sensitive to slice preparation and are either not viable, or their spontaneous activity is eliminated under suboptimal conditions. GoCs might therefore be particularly susceptible to damage in vivo, e.g., to acidosis and calcium overload during ischemia (Huang et al., 2010). Given the importance of GoCs to cerebellar function, it is tempting to speculate GoC damage could contribute to cerebellar disorders such as ataxia.

\section{Calcium and potassium channels near the soma control action potential firing in GoCs}

We find that the characteristic spontaneous GoC firing requires an interplay between calcium influx through $\mathrm{N}$-type calcium channels and $\mathrm{K}_{\mathrm{Ca}}$ channels near the soma. Two types of $\mathrm{K}_{\mathrm{Ca}}$ channels are involved. Calcium and voltage-sensitive BK-type channels rapidly help to terminate the action potential, whereas 
calcium-sensitive SK channels contribute to afterhyperpolarization in GoCs. Blocking N-type calcium channels recapitulates inhibition of $\mathrm{K}_{\mathrm{Ca}}$ channels, whereas the blockade of the other calcium channel types (R-type, T-type, L-type, and P-type) does not have a major effect on action potential properties or the regularity of firing. $\mathrm{N}$-type calcium channels thus activate both SK and BK channels. Strikingly, introduction of exogenous buffers with different binding rates revealed that $\mathrm{N}$-type channels are tightly coupled to both BK and SK channels. Both types of $\mathrm{K}_{\mathrm{Ca}}$ channels have been described to interact with various VGCC subtypes (Marrion and Tavalin, 1998; Wolfart and Roeper, 2002; Womack et al., 2004; Jones and Stuart, 2013), but only BK channels form tight complexes with VGCCs, ensuring local calcium concentrations are sufficiently high for reliable activation (Berkefeld et al., 2006). In GoCs, a tight spatial relationship of BK and $\mathrm{N}$-type channels permits narrow spikes and rapid repolarization. Because of their high affinity to calcium, SK channels often couple loosely and promiscuously to VGCCs, although nanodomain coupling can occur (Fakler and Adelman, 2008; Jones and Stuart, 2013). In GoCs, where the overall density of calcium channels, and therefore bulk calcium entry, is low the short intermolecular distance between $\mathrm{N}$-type and SK channels ensures their rapid and specific activation required for regular spiking. We propose that nanodomain coupling between $\mathrm{N}$-type calcium channels and $\mathrm{K}_{\mathrm{Ca}}$ channels allows for precise spatiotemporal control of membrane potential and enables GoCs to fire spontaneously with great regularity and reliability over a range of different frequencies.

\section{References}

Abrahamsson T, Cathala L, Matsui K, Shigemoto R, Digregorio DA (2012) Thin dendrites of cerebellar interneurons confer sublinear synaptic integration and a gradient of short-term plasticity. Neuron 73:1159-1172. CrossRef Medline

Acuna-Goycolea C, Brenowitz SD, Regehr WG (2008) Active dendritic conductances dynamically regulate GABA release from thalamic interneurons. Neuron 57:420-431. CrossRef Medline

Adler EM, Augustine GJ, Duffy SN, Charlton MP (1991) Alien intracellular calcium chelators attenuate neurotransmitter release at the squid giant synapse. J Neurosci 11:1496-1507. Medline

Aizenman CD, Manis PB, Linden DJ (1998) Polarity of long-term synaptic gain change is related to postsynaptic spike firing at a cerebellar inhibitory synapse. Neuron 21:827-835. CrossRef Medline

Alle H, Kubota H, Geiger JR (2011) Sparse but highly efficient Kv3 outpace BKCa channels in action potential repolarization at hippocampal mossy fiber boutons. J Neurosci 31:8001-8012. CrossRef Medline

Aponte Y, Bischofberger J, Jonas P (2008) Efficient $\mathrm{Ca}^{2+}$ buffering in fastspiking basket cells of rat hippocampus. J Physiol 586:2061-2075. CrossRef Medline

Barmack NH, Yakhnitsa V (2008) Functions of interneurons in mouse cerebellum. J Neurosci 28:1140-1152. CrossRef Medline

Bennett MV, Zukin RS (2004) Electrical coupling and neuronal synchronization in the Mammalian brain. Neuron 41:495-511. CrossRef Medline

Benton MD, Lewis AH, Bant JS, Raman IM (2013) Iberiotoxin-sensitive and -insensitive BK currents in Purkinje neuron somata. J Neurophysiol 109: 2528-2541. CrossRef Medline

Berkefeld H, Sailer CA, Bildl W, Rohde V, Thumfart JO, Eble S, Klugbauer N, Reisinger E, Bischofberger J, Oliver D, Knaus HG, Schulte U, Fakler B (2006) BKCa-Cav channel complexes mediate rapid and localized $\mathrm{Ca}^{2+}$ activated K+ signaling. Science 314:615-620. CrossRef Medline

Bloodgood BL, Sabatini BL (2007) Nonlinear regulation of unitary synaptic signals by $\mathrm{CaV}(2.3)$ voltage-sensitive calcium channels located in dendritic spines. Neuron 53:249-260. CrossRef Medline

Branco T, Häusser M (2011) Synaptic integration gradients in single cortical pyramidal cell dendrites. Neuron 69:885-892. CrossRef Medline

Brenowitz SD, Regehr WG (2007) Reliability and heterogeneity of calcium signaling at single presynaptic boutons of cerebellar granule cells. J Neurosci 27:7888-7898. CrossRef Medline
Brickley SG, Cull-Candy SG, Farrant M (1996) Development of a tonic form of synaptic inhibition in rat cerebellar granule cells resulting from persistent activation of GABAA receptors. J Physiol 497:753-759. CrossRef Medline

Casale AE, McCormick DA (2011) Active action potential propagation but not initiation in thalamic interneuron dendrites. J Neurosci 31:18289_ 18302. CrossRef Medline

Cesana E, Pietrajtis K, Bidoret C, Isope P, D’Angelo E, Dieudonné S, Forti L (2013) Granule cell ascending axon excitatory synapses onto Golgi cells implement a potent feedback circuit in the cerebellar granular layer. J Neurosci 33:12430-12446. CrossRef Medline

Chadderton P, Margrie TW, Häusser M (2004) Integration of quanta in cerebellar granule cells during sensory processing. Nature 428:856-860. CrossRef Medline

Chan-Palay V, Palay SL (1971a) Tendril and glomerular collaterals of climbing fibers in the granular layer of the rat's cerebellar cortex. Z Anat Entwicklungsgesch 133:247-273. CrossRef Medline

Chan-Palay V, Palay SL (1971b) The synapse en marron between golgi II neurons and mossy fibers in the rat's cerebellar cortex. Z Anat Entwicklungsgesch 133:274-287. CrossRef Medline

Connors BW, Long MA (2004) Electrical synapses in the mammalian brain. Annu Rev Neurosci 27:393-418. CrossRef Medline

Coulon P, Herr D, Kanyshkova T, Meuth P, Budde T, Pape HC (2009) Burst discharges in neurons of the thalamic reticular nucleus are shaped by calcium-induced calcium release. Cell Calcium 46:333-346. CrossRef Medline

Crowley JJ, Fioravante D, Regehr WG (2009) Dynamics of fast and slow inhibition from cerebellar golgi cells allow flexible control of synaptic integration. Neuron 63:843-853. CrossRef Medline

Cueni L, Canepari M, Luján R, Emmenegger Y, Watanabe M, Bond CT, Franken P, Adelman JP, Lüthi A (2008) T-type $\mathrm{Ca}^{2+}$ channels, SK2 channels and SERCAs gate sleep-related oscillations in thalamic dendrites. Nat Neurosci 11:683-692. CrossRef Medline

Deignan J, Luján R, Bond C, Riegel A, Watanabe M, Williams JT, Maylie J, Adelman JP (2012) SK2 and SK3 expression differentially affect firing frequency and precision in dopamine neurons. Neuroscience 217:67-76. CrossRef Medline

Dieudonné S (1998) Submillisecond kinetics and low efficacy of parallel fibre-Golgi cell synaptic currents in the rat cerebellum. J Physiol 510: 845-866. CrossRef Medline

Dieudonné S, Dumoulin A (2000) Serotonin-driven long-range inhibitory connections in the cerebellar cortex. J Neurosci 20:1837-1848. Medline

Dugué GP, Dumoulin A, Triller A, Dieudonné S (2005) Target-dependent use of co-released inhibitory transmitters at central synapses. J Neurosci 25:6490-6498. CrossRef Medline

Dugué GP, Brunel N, Hakim V, Schwartz E, Chat M, Lévesque M, Courtemanche R, Léna C, Dieudonné S (2009) Electrical coupling mediates tunable low-frequency oscillations and resonance in the cerebellar Golgi cell network. Neuron 61:126-139. CrossRef Medline

Duguid I, Branco T, London M, Chadderton P, Häusser M (2012) Tonic inhibition enhances fidelity of sensory information transmission in the cerebellar cortex. J Neurosci 32:11132-11143. CrossRef Medline

Eccles J, Llinás R, Sasaki K (1964) Golgi cell inhibition in the cerebellar cortex. Nature 204:1265-1266. CrossRef Medline

Eggermann E, Bucurenciu I, Goswami SP, Jonas P (2012) Nanodomain coupling between $\mathrm{Ca}^{2+}$ channels and sensors of exocytosis at fast mammalian synapses. Nat Rev Neurosci 13:7-21. CrossRef Medline

Engbers JDT, Anderson D, Asmara H, Rehak R, Mehaffey WH, Hameed S, McKay BE, Kruskic M, Zamponi GW, Turner RW (2012) Intermediate conductance calcium-activated potassium channels modulate summation of parallel fiber input in cerebellar Purkinje cells. Proc Natl Acad Sci U S A 109:2601-2606. CrossRef Medline

Errington AC, Renger JJ, Uebele VN, Crunelli V (2010) State-dependent firing determines intrinsic dendritic $\mathrm{Ca}^{2+}$ signaling in thalamocortical neurons. J Neurosci 30:14843-14853. CrossRef Medline

Evstratova A, Chamberland S, Topolnik L (2011) Cell type-specific and activity-dependent dynamics of action potential-evoked $\mathrm{Ca}^{2+}$ signals in dendrites of hippocampal inhibitory interneurons. J Physiol 589:19571977. CrossRef Medline

Fakler BB, Adelman JPJ (2008) Control of K(Ca) channels by calcium nano/ microdomains. Neuron 59:9. CrossRef Medline

Forti L, Cesana E, Mapelli J, D’Angelo E (2006) Ionic mechanisms of auto- 
rhythmic firing in rat cerebellar Golgi cells. J Physiol 574:711-729. CrossRef Medline

Geurts FJ, Timmermans J, Shigemoto R, De Schutter E (2001) Morphological and neurochemical differentiation of large granular layer interneurons in the adult rat cerebellum. Neuroscience 104:499-512. CrossRef Medline

Goldberg JH, Yuste R (2005) Space matters: local and global dendritic $\mathrm{Ca}^{2+}$ compartmentalization in cortical interneurons. Trends Neurosci 28:158167. CrossRef Medline

Goldberg JH, Tamas G, Aronov D, Yuste R (2003) Calcium microdomains in aspiny dendrites. Neuron 40:807-821. CrossRef Medline

Goldberg JH, Lacefield CO, Yuste R (2004) Global dendritic calcium spikes in mouse layer 5 low threshold spiking interneurones: implications for control of pyramidal cell bursting. J Physiol 558:465-478. CrossRef Medline

Grynkiewicz G, Poenie M, Tsien RY (1985) A new generation of $\mathrm{Ca}^{2+}$ indicators with greatly improved fluorescence properties. J Biol Chem 260: 3440-3450. Medline

Hamann M, Rossi DJ, Attwell D (2002) Tonic and spillover inhibition of granule cells control information flow through cerebellar cortex. Neuron 33:625-633. CrossRef Medline

Heine SA, Highstein SM, Blazquez PM (2010) Golgi cells operate as statespecific temporal filters at the input stage of the cerebellar cortex. J Neurosci 30:17004-17014. CrossRef Medline

Helmchen F, Imoto K, Sakmann B (1996) $\mathrm{Ca}^{2+}$ buffering and action potential-evoked $\mathrm{Ca}^{2+}$ signaling in dendrites of pyramidal neurons. Biophys J 70:1069-1081. CrossRef Medline

Helmchen F, Borst JG, Sakmann B (1997) Calcium dynamics associated with a single action potential in a CNS presynaptic terminal. Biophys J 72:1458-1471. CrossRef Medline

Hu H, Martina M, Jonas P (2010) Dendritic mechanisms underlying rapid synaptic activation of fast-spiking hippocampal interneurons. Science 327:52-58. CrossRef Medline

Huang L, Chen N, Ge M, Zhu Y, Guan S, Wang JH (2010) $\mathrm{Ca}^{2+}$ and acidosis synergistically lead to the dysfunction of cortical GABAergic neurons during ischemia. Biochem Biophys Res Commun 394:709-714. CrossRef Medline

Huguenard JR, Prince DA (1992) A novel T-type current underlies prolonged $\mathrm{Ca}(2+)$-dependent burst firing in GABAergic neurons of rat thalamic reticular nucleus. J Neurosci 12:3804-3817. Medline

Hull C, Regehr WG (2012) Identification of an inhibitory circuit that regulates cerebellar Golgi cell activity. Neuron 73:149-158. CrossRef Medline

Hull CA, Chu Y, Thanawala M, Regehr WG (2013) Hyperpolarization induces a long-term increase in the spontaneous firing rate of cerebellar Golgi cells. J Neurosci 33:5895-5902. CrossRef Medline

Isaacson JS, Scanziani M (2011) How inhibition shapes cortical activity. Neuron 72:231-243. CrossRef Medline

Johnston D, Magee JC, Colbert CM, Cristie BR (1996) Active properties of neuronal dendrites. Annu Rev Neurosci 19:165-186. CrossRef Medline

Jones SL, Stuart GJ (2013) Different calcium sources control somatic versus dendritic SK channel activation during action potentials. J Neurosci 33: 19396-19405. CrossRef Medline

Kaiser KM, Lübke J, Zilberter Y, Sakmann B (2004) Postsynaptic calcium influx at single synaptic contacts between pyramidal neurons and bitufted interneurons in layer $2 / 3$ of rat neocortex is enhanced by backpropagating action potentials. J Neurosci 24:1319-1329. CrossRef Medline

Kaiser KM, Zilberter Y, Sakmann B (2001) Back-propagating action potentials mediate calcium signalling in dendrites of bitufted interneurons in layer 2/3 of rat somatosensory cortex. J Physiol 535:17-31. CrossRef Medline

Kanichay RT, Silver RA (2008) Synaptic and cellular properties of the feedforward inhibitory circuit within the input layer of the cerebellar cortex. J Neurosci 28:8955-8967. CrossRef Medline

Lancaster B, Nicoll RA (1987) Properties of two calcium-activated hyperpolarizations in rat hippocampal neurones. J Physiol 389:187-203. CrossRef Medline

Lee SH, Rosenmund C, Schwaller B, Neher E (2000) Differences in $\mathrm{Ca}^{2+}$ buffering properties between excitatory and inhibitory hippocampal neurons from the rat. J Physiol 525:405-418. CrossRef Medline

Llinás R, Sugimori M, Simon SM (1982) Transmission by presynaptic spike-like depolarization in the squid giant synapse. Proc Natl Acad Sci U S A 79:2415-2419. CrossRef Medline
Magee JC, Johnston D (1995) Characterization of single voltage-gated $\mathrm{Na}+$ and $\mathrm{Ca}^{2+}$ channels in apical dendrites of rat CA1 pyramidal neurons. J Physiol 487:67-90. CrossRef Medline

Major G, Larkum ME, Schiller J (2013) Active properties of neocortical pyramidal neuron dendrites. Annu Rev Neurosci 36:1-24. CrossRef Medline

Maravall M, Mainen ZF, Sabatini BL, Svoboda K (2000) Estimating intracellular calcium concentrations and buffering without wavelength ratioing. Biophys J 78:2655-2667. CrossRef Medline

Marrion NV, Tavalin SJ (1998) Selective activation of $\mathrm{Ca}^{2+}$-activated K+ channels by co-localized $\mathrm{Ca}^{2+}$ channels in hippocampal neurons. Nature 395:900-905. CrossRef Medline

Martina M, Vida I, Jonas P (2000) Distal initiation and active propagation of action potentials in interneuron dendrites. Science 287:295-300. CrossRef Medline

Matthews EA, Dietrich D (2015) Buffer mobility and the regulation of neuronal calcium domains. Front Cell Neurosci 9:48. CrossRef Medline

Midtgaard J (1992) Membrane properties and synaptic responses of Golgi cells and stellate cells in the turtle cerebellum in vitro. J Physiol 457: 329-354. CrossRef Medline

Mintz IM, Sabatini BL, Regehr WG (1995) Calcium control of transmitter release at a cerebellar synapse. Neuron 15:675-688. CrossRef Medline

Mitchell SJ, Silver RA (2003) Shunting inhibition modulates neuronal gain during synaptic excitation. Neuron 38:433-445. CrossRef Medline

Mittmann W, Koch U, Häusser M (2005) Feed-forward inhibition shapes the spike output of cerebellar Purkinje cells. J Physiol 563:369-378. CrossRef Medline

Molineux ML, McRory JE, McKay BE, Hamid J, Mehaffey WH, Rehak R, Snutch TP, Zamponi GW, Turner RW (2006) Specific T-type calcium channel isoforms are associated with distinct burst phenotypes in deep cerebellar nuclear neurons. Proc Natl Acad Sci U S A 103:5555-5560. CrossRef Medline

Myoga MH, Beierlein M, Regehr WG (2009) Somatic spikes regulate dendritic signaling in small neurons in the absence of backpropagating action potentials. J Neurosci 29:7803-7814. CrossRef Medline

Neher E, Augustine GJ (1992) Calcium gradients and buffers in bovine chromaffin cells. J Physiol 450:273-301. CrossRef Medline

Ngo-Anh TJ, Bloodgood BL, Lin M, Sabatini BL, Maylie J, Adelman JP (2005) SK channels and NMDA receptors form a $\mathrm{Ca}^{2+}$-mediated feedback loop in dendritic spines. Nat Neurosci 8:642-649. CrossRef Medline

Ohtsuki G, Piochon C, Adelman JP, Hansel C (2012) SK2 channel modulation contributes to compartment-specific dendritic plasticity in cerebellar Purkinje cells. Neuron 75:108-120. CrossRef Medline

Palkovits M, Magyar P, Szentágothai J (1971) Quantitative histological analysis of the cerebellar cortex in the cat: 3 . Structural organization of the molecular layer. Brain Res 34:1-18. CrossRef Medline

Pellionisz A, Szentágothai J (1973) Dynamic single unit simulation of a realistic cerebellar network model. Brain Res 49:83-99. CrossRef Medline

Pouille F, Scanziani M (2001) Enforcement of temporal fidelity in pyramidal cells by somatic feed-forward inhibition. Science 293:1159-1163. CrossRef Medline

Pressler RT, Rozman PA, Strowbridge BW (2013) Voltage-dependent intrinsic bursting in olfactory bulb Golgi cells. Learn Mem 20:459-466. CrossRef Medline

Rossi DJ, Hamann M (1998) Spillover-mediated transmission at inhibitory synapses promoted by high affinity alpha6 subunit $\mathrm{GABA}(\mathrm{A})$ receptors and glomerular geometry. Neuron 20:783-795. CrossRef Medline

Rózsa B, Zelles T, Vizi ES, Lendvai B (2004) Distance-dependent scaling of calcium transients evoked by backpropagating spikes and synaptic activity in dendrites of hippocampal interneurons. J Neurosci 24:661-670. CrossRef Medline

Sabatini BL, Oertner TG, Svoboda K (2002) The life cycle of $\mathrm{Ca}(2+)$ ions in dendritic spines. Neuron 33:439-452. CrossRef Medline

Schneider ER, Civillico EF, Wang SS (2013) Calcium-based dendritic excitability and its regulation in the deep cerebellar nuclei. J Neurophysiol 109:2282-2292. CrossRef Medline

Schwaller B (2010) Cytosolic $\mathrm{Ca}^{2+}$ buffers. Cold Spring Harb Perspect Biol 2:a004051. CrossRef Medline

Simat M, Parpan F, Fritschy JM (2007) Heterogeneity of glycinergic and gabaergic interneurons in the granule cell layer of mouse cerebellum. J Comp Neurol 500:71-83. CrossRef Medline

Soler-Llavina GJ, Sabatini BL (2006) Synapse-specific plasticity and com- 
partmentalized signaling in cerebellar stellate cells. Nat Neurosci 9:798806. CrossRef Medline

Solinas S, Forti L, Cesana E, Mapelli J, De Schutter E, D’Angelo E (2007) Fast-reset of pacemaking and theta-frequency resonance patterns in cerebellar golgi cells: simulations of their impact in vivo. Front Cell Neurosci 1:4. CrossRef Medline

Somogyi P, Klausberger T (2005) Defined types of cortical interneurone structure space and spike timing in the hippocampus. J Physiol 562:9-26. CrossRef Medline

Stuart G, Häusser M (1994) Initiation and spread of sodium action potentials in cerebellar Purkinje cells. Neuron 13:703-712. CrossRef Medline

Swensen AM, Bean BP (2003) Ionic mechanisms of burst firing in dissociated Purkinje neurons. J Neurosci 23:9650-9663. Medline

Vervaeke K, Lorincz A, Gleeson P, Farinella M, Nusser Z, Silver RA (2010) Rapid desynchronization of an electrically coupled interneuron network with sparse excitatory synaptic input. Neuron 67:435-451. CrossRef Medline

Vervaeke K, Lorincz A, Nusser Z, Silver RA (2012) Gap junctions compensate for sublinear dendritic integration in an inhibitory network. Science 335:1624-1628. CrossRef Medline

Vos BP, Volny-Luraghi A, De Schutter E (1999) Cerebellar Golgi cells in the rat: receptive fields and timing of responses to facial stimulation. Eur J Neurosci 11:2621-2634. CrossRef Medline

Watanabe D, Nakanishi S (2003) mGluR2 postsynaptically senses granule cell inputs at Golgi cell synapses. Neuron 39:821-829. CrossRef Medline

Watanabe D, Inokawa H, Hashimoto K, Suzuki N, Kano M, Shigemoto R, Hirano T, Toyama K, Kaneko S, Yokoi M, Moriyoshi K, Suzuki M, Ko- bayashi K, Nagatsu T, Kreitman RJ, Pastan I, Nakanishi S (1998) Ablation of cerebellar Golgi cells disrupts synaptic integration involving GABA inhibition and NMDA receptor activation in motor coordination. Cell 95:17-27. CrossRef Medline

Williams SR, Stuart GJ (1999) Mechanisms and consequences of action potential burst firing in rat neocortical pyramidal neurons. J Physiol 521: 467-482. CrossRef Medline

Wolfart J, Roeper J (2002) Selective coupling of T-type calcium channels to SK potassium channels prevents intrinsic bursting in dopaminergic midbrain neurons. J Neurosci 22:3404-3413. Medline

Wolfart J, Neuhoff H, Franz O, Roeper J (2001) Differential expression of the small-conductance, calcium-activated potassium channel SK3 is critical for pacemaker control in dopaminergic midbrain neurons. J Neurosci 21:3443-3456. Medline

Womack MD, Khodakhah K (2003) Somatic and dendritic smallconductance calcium-activated potassium channels regulate the output of cerebellar Purkinje neurons. J Neurosci 23:2600-2607. Medline

Womack MD, Khodakhah K (2004) Dendritic control of spontaneous bursting in cerebellar Purkinje cells. J Neurosci 24:3511-3521. CrossRef Medline

Womack MD, Chevez C, Khodakhah K (2004) Calcium-activated potassium channels are selectively coupled to $\mathrm{P} / \mathrm{Q}$-type calcium channels in cerebellar Purkinje neurons. J Neurosci 24:8818-8822. CrossRef Medline

Yaeger DB, Trussell LO (2015) Single granule cells excite Golgi cells and evoke feedback inhibition in the cochlear nucleus. J Neurosci 35: 4741-4750. CrossRef Medline 